\title{
CCN activity and organic hygroscopicity of aerosols downwind of an urban region in central Amazonia: seasonal and diel variations and impact of anthropogenic emissions
}

\author{
Ryan Thalman ${ }^{1, a}$, Suzane S. de Sá ${ }^{2}$, Brett B. Palm ${ }^{3}$, Henrique M. J. Barbosa ${ }^{4}$, Mira L. Pöhlker ${ }^{5}$, \\ M. Lizabeth Alexander ${ }^{7}$, Joel Brito ${ }^{4, b}$, Samara Carbone ${ }^{4}$, Paulo Castillo ${ }^{1}$, Douglas A. Day ${ }^{3}$, Chongai Kuang ${ }^{1}$, \\ Antonio Manzi $^{8}$, Nga Lee Ng ${ }^{9,10}$, Arthur J. Sedlacek III ${ }^{1}$, Rodrigo Souza ${ }^{11}$, Stephen Springston ${ }^{1}$, Thomas Watson ${ }^{1}$, \\ Christopher Pöhlker ${ }^{5}$, Ulrich Pöschl ${ }^{5}$, Meinrat O. Andreae ${ }^{5,6}$, Paulo Artaxo ${ }^{4}$, Jose L. Jimenez ${ }^{3}$, Scot T. Martin $^{2,12}$, \\ and Jian Wang ${ }^{1}$ \\ ${ }^{1}$ Environmental and Climate Sciences Department, Brookhaven National Laboratory, Upton, NY, USA \\ ${ }^{2}$ School of Engineering and Applied Sciences, Harvard University, Cambridge, MA, USA \\ ${ }^{3}$ Department of Chemistry and Biochemistry and Cooperative Institute for Research in Environmental Sciences (CIRES), \\ University of Colorado Boulder, Boulder, CO, USA \\ ${ }^{4}$ Physics Institute, University of São Paulo, São Paulo, Brazil \\ ${ }^{5}$ Biogeochemistry and Multiphase Chemistry Departments, Max Planck Institute for Chemistry, Mainz, Germany \\ ${ }^{6}$ Scripps Institution of Oceanography, University of California San Diego, La Jolla, CA, USA \\ ${ }^{7}$ Pacific Northwest National Laboratory, Richland, WA, USA \\ ${ }^{8}$ National Institute of Amazonian Research, Manaus, Amazonas, Brazil \\ ${ }^{9}$ School of Chemical and Biomolecular Engineering, Georgia Institute of Technology, Atlanta, GA, USA \\ ${ }^{10}$ School of Earth and Atmospheric Sciences, Georgia Institute of Technology, Atlanta, GA, USA \\ ${ }^{11}$ Amazonas State University, Manaus, Amazonas, Brazil \\ ${ }^{12}$ Department of Earth and Planetary Sciences, Harvard University, Cambridge, MA, USA \\ anow at: Department of Chemistry, Snow College, Richfield, UT, USA \\ ${ }^{b}$ now at: Laboratory for Meteorological Physics, Université Clermont Auvergne, Clermont-Ferrand, France
}

Correspondence to: Jian Wang (jian@bnl.gov)

Received: 17 March 2017 - Discussion started: 28 March 2017

Revised: 4 August 2017 - Accepted: 16 August 2017 - Published: 5 October 2017

\begin{abstract}
During the Observations and Modeling of the Green Ocean Amazon (GoAmazon2014/5) campaign, sizeresolved cloud condensation nuclei $(\mathrm{CCN})$ spectra were characterized at a research site (T3) $60 \mathrm{~km}$ downwind of the city of Manaus, Brazil, in central Amazonia for 1 year (12 March 2014 to 3 March 2015). Particle hygroscopicity $\left(\kappa_{\mathrm{CCN}}\right)$ and mixing state were derived from the size-resolved CCN spectra, and the hygroscopicity of the organic component of the aerosol $\left(\kappa_{\mathrm{org}}\right)$ was then calculated from $\kappa_{\mathrm{CCN}}$ and concurrent chemical composition measurements. The annual average $\kappa_{\mathrm{CCN}}$ increased from 0.13 at $75 \mathrm{~nm}$ to 0.17 at $171 \mathrm{~nm}$, and the increase was largely due to an increase in sulfate volume fraction. During both wet and dry seasons, $\kappa_{\mathrm{CCN}}, \kappa_{\mathrm{org}}$, and particle composition under background con-
\end{abstract}

ditions exhibited essentially no diel variations. The constant $\kappa_{\text {org }}$ of $\sim 0.15$ is consistent with the largely uniform and high $\mathrm{O}: \mathrm{C}$ value $(\sim 0.8)$, indicating that the aerosols under background conditions are dominated by the aged regional aerosol particles consisting of highly oxygenated organic compounds. For air masses strongly influenced by urban pollution and/or local biomass burning, lower values of $\kappa_{\text {org }}$ and organic $\mathrm{O}: \mathrm{C}$ atomic ratio were observed during night, due to accumulation of freshly emitted particles, dominated by primary organic aerosol (POA) with low hygroscopicity, within a shallow nocturnal boundary layer. The $\mathrm{O}: \mathrm{C}, \kappa_{\mathrm{org}}$, and $\kappa_{\mathrm{CCN}}$ increased from the early morning hours and peaked around noon, driven by the formation and aging of secondary organic aerosol (SOA) and dilution of POA emissions into a deeper 
boundary layer, while the development of the boundary layer, which leads to mixing with aged particles from the residual layer aloft, likely also contributed to the increases. The hygroscopicities associated with individual organic factors, derived from PMF (positive matrix factorization) analysis of AMS (aerosol mass spectrometry) spectra, were estimated through multivariable linear regression. For the SOA factors, the variation of the $\kappa$ value with $\mathrm{O}: \mathrm{C}$ agrees well with the linear relationship reported from earlier laboratory studies of SOA hygroscopicity. On the other hand, the variation in $\mathrm{O}: \mathrm{C}$ of ambient aerosol organics is largely driven by the variation in the volume fractions of POA and SOA factors, which have very different $\mathrm{O}: \mathrm{C}$ values. As POA factors have hygroscopicity values well below the linear relationship between SOA hygroscopicity and $\mathrm{O}: \mathrm{C}$, mixtures with different POA and SOA fractions exhibit a steeper slope for the increase in $\kappa_{\text {org }}$ with $\mathrm{O}: \mathrm{C}$, as observed during this and earlier field studies. This finding helps better understand and reconcile the differences in the relationships between $\kappa_{\text {org }}$ and $\mathrm{O}: \mathrm{C}$ observed in laboratory and field studies, therefore providing a basis for improved parameterization in global models, especially in a tropical context.

\section{Introduction}

Atmospheric aerosols have a major impact on the radiative balance of the Earth's climate system by changing the microphysical structure, lifetime, and coverage of clouds. For the same liquid water content, high aerosol concentration leads to more, smaller cloud droplets and therefore higher cloud albedo (Twomey, 1977). The smaller droplet size also delays or inhibits warm precipitation, leading to increases in both cloud lifetime and coverage (Albrecht, 1989) and ultimately invigoration of convective clouds (Rosenfeld et al., 2008). Currently, the effects of aerosol on clouds remain one of the largest uncertainties in simulated climate change during the industrial era, and a large portion of this uncertainty is due to the natural aerosol properties and processes represented in models (Carslaw et al., 2013; Ghan et al., 2013). The Amazon represents more than half of the planet's rainforest and is a rapidly changing region where deforestation, human activity, and natural resource needs are all at play in changing the ecosystem (Andreae et al., 2015; Batistella et al., 2009; Davidson et al., 2012). The Amazon basin also represents at times one of the cleanest continental regions on the planet where it is still possible to find extended periods with little or no impact of anthropogenic activity, although the longdistance transport of pollution is occasionally observed (Andreae et al., 2015; Hamilton et al., 2014; Martin et al., 2010b; Wang et al., 2016a, b; Williams et al., 2002). This makes the Amazon basin an ideal location to characterize aerosol under near-natural conditions and assess the impact due to urban emissions and biomass burning (Kuhn et al., 2010).
The biogenic activity of this region makes it a major source of organic carbon released into the atmosphere via isoprene and monoterpenes (Guenther et al., 2006, 2012; Kesselmeier et al., 2002; Kuhn et al., 2007) which are mediated by biotic stress through heat, sunlight, and changes in $\mathrm{CO}_{2}$ (Heald et al., 2009).

To understand the impact of aerosol on clouds and climate requires knowledge of the concentration of cloud condensation nuclei $(\mathrm{CCN})$, which are particles that are able to form cloud droplets under relevant atmospheric conditions. The minimum supersaturation required to activate a particle into a cloud droplet can be predicted using the $\kappa$-Köhler theory based on particle size and the single hygroscopicity parameter $\kappa$, which combines a number of thermodynamic properties required for the description of water activity of the growing droplets (Petters and Kreidenweis, 2007). The value of $\kappa$ is determined by the physicochemical properties of the solutes, including their molar volume, activity coefficient, and the effect on surface tension. For multicomponent particles, $\kappa$ is the volume average of participating species. Hygroscopicity also describes particle growth under subsaturated conditions and can be derived from the particle growth factor (GF). However, particles sometime exhibit larger $\kappa$ values for droplet activation (derived from $\mathrm{CCN}$ measurements under supersaturated conditions) than for particle growth (derived from particle GF under subsaturated conditions; e.g., Duplissy et al., 2008; Good et al., 2010; Mikhailov et al., 2013; Pajunoja et al., 2015; Wex et al., 2009). In this paper, "hygroscopicity" represents $\kappa$ associated with droplet activation derived from $\mathrm{CCN}$ measurements unless noted otherwise.

The hygroscopicities of typical inorganic species in ambient particles are relatively well known (Petters and Kreidenweis, 2007). However, atmospheric aerosols consist of a large number of organic compounds, which often dominate the total fine aerosol mass, especially in forested areas (e.g., de Sá et al., 2017a; Jimenez et al., 2009; Zhang et al., 2007). The hygroscopicity of aerosol organics $\left(\kappa_{\text {org }}\right)$ have been examined in both laboratory (e.g., Asa-Awuku et al., 2009; Duplissy et al., 2011; King et al., 2009; Lambe et al., 2011; Massoli et al., 2010; Prenni et al., 2007; Raymond and Pandis, 2003) and field studies (e.g., Cerully et al., 2015; Chang et al., 2010; Dusek et al., 2010; Gunthe et al., 2009; Jimenez et al., 2009; Lathem et al., 2013; Mei et al., 2013a, b; Moore et al., 2011, 2012; Pöhlker et al., 2016; Rose et al., 2010; Shantz et al., 2008; Wang et al., 2008). Overall, these studies show that aerosol organics exhibit a wide range of $\kappa$ values from 0 to $\sim 0.3$, and $\kappa_{\text {org }}$ often increases substantially during aerosol aging in the atmosphere (e.g., Duplissy et al., 2011; Jimenez et al., 2009; Lambe et al., 2011; Massoli et al., 2010; Mei et al., 2013a, b).

A number of recent studies examined the sensitivity of predicted CCN concentration and cloud droplet number concentration to aerosol properties (e.g., Ervens et al., 2010; Kammermann et al., 2010; McFiggans et al., 2006; Mei et al., 
2013b; Reutter et al., 2009; Rissman et al., 2004; Roberts et al., 2002; Wang, 2007; Wang et al., 2008). These studies show that the predicted CCN concentration is often sensitive to $\kappa_{\text {org }}$, especially for aerosol under background conditions where organics tend to dominate submicron aerosol mass (Liu and Wang, 2010; Mei et al., 2013b). Using a constant $\kappa_{\text {org }}$ may lead to large biases in predicted CCN concentrations and aerosol indirect forcing (Liu and Wang, 2010). Therefore, it is imperative to understand organic hygroscopicity under background conditions, such as in the Amazon forest, as well as the variation of organic hygroscopicity due to anthropogenic emissions.

There have been several studies of aerosol hygroscopicity in the Amazon basin over the past 20 years (Gunthe et al., 2009; Mikhailov et al., 2013; Pöhlker et al., 2016; Rissler et al., 2006; Roberts et al., 2001; Vestin et al., 2007; Whitehead et al., 2016; Zhou et al., 2002). Gunthe et al. (2009) performed size-resolved $\mathrm{CCN}$ measurements during the wet season in February and March 2008 as part of the AMAZE08 campaign (Martin et al., 2010a). That study reported no diel cycle in the $\mathrm{CCN}$ concentration during periods with little or no influence of pollution. Pöhlker et al. (2016) measured size-resolved CCN spectra at a remote background site (Amazon Tall Tower Observatory, ATTO) over a 1-year period from March 2014 to February 2015 and observed no diel cycle and only weak seasonal trends in derived particle hygroscopicity $\left(\kappa_{\mathrm{CCN}}\right)$, while $\mathrm{CCN}$ concentrations had a pronounced seasonal cycle as the background aerosol concentration was strongly influenced by regional biomass burning during the dry season. During the SMOCC-2002 campaign (LBA-SMOCC; Large-Scale Biosphere-Atmosphere Experiment in Amazonia - SMOke, Aerosols, Clouds, Rainfall, and Climate), particle hygroscopicity was derived from the Humidified Tandem Differential Mobility Analyzer measurements in the state of Rondônia in the southwest of the Amazon region during the dry season from September to November of 2002 (Rissler et al., 2006; Vestin et al., 2007). The study concluded that the diel variation in the aerosol hygroscopicity could be linked to the structure and dynamics of the boundary layer. Local sources dominated nighttime aerosol properties with downward mixing from the residual layer aloft as the day progressed. All of these studies found that particle hygroscopicity increased with particle size (from the Aitken to accumulation modes), consistent with higher sulfate content at larger sizes (Gunthe et al., 2009). The same boundary layer evolution has been found to influence particle number and $\mathrm{CCN}$ evolution in a number of other related studies (Fisch et al., 2004; Martin et al., 2010a; Rissler et al., 2006; Vestin et al., 2007; Whitehead et al., 2010; Zhou et al., 2002).

In this study we present measurements of size-resolved $\mathrm{CCN}$ spectra at five particle diameters ranging from 75 to $171 \mathrm{~nm}$ downwind of Manaus, Brazil, in central Amazonia for a period of 1 year from 12 March 2014 to 3 March 2015. Particle hygroscopicity, mixing state, and organic hygroscop- icity are derived from the size-resolved-CCN activated fraction and concurrent aerosol composition measurements. The diel variations of these properties are examined for different seasons (i.e., wet season, dry season, and transition seasons) and for different types of representative air masses, including background conditions, as well as influences of urban pollution plumes and/or local biomass burning. During the wet season, the background air mass represents near-natural conditions, with occasional impact from anthropogenic emissions, while, in the dry season, the background is dominated by regional biomass burning aerosol particles. The relationship between organic hygroscopicity and particle oxidation level (i.e., $\mathrm{O}: \mathrm{C}$ atomic ratio) is examined for both dry and wet seasons. Hygroscopicities associated with organic factors from aerosol mass spectrometry (AMS) positive matrix factorization (PMF) analysis are derived, and their relationship with the $\mathrm{O}: \mathrm{C}$ ratio is compared with those from previous laboratory studies.

\section{Experimental setup}

\subsection{Measurement sites}

Observations and Modeling of the Green Ocean Amazon (GoAmazon2014/5), sponsored by the US Department of Energy and several Brazilian and German agencies, took place at multiple surface sites surrounding Manaus, Brazil, from January 2014 through December 2015 (Martin et al., 2016). This work focuses on the measurements carried out at a downwind site (T3; $3^{\circ} 12^{\prime} 47.82^{\prime \prime} \mathrm{S}, 60^{\circ} 35^{\prime} 55.32^{\prime \prime} \mathrm{W}$; $60 \mathrm{~km}$ west of Manaus) from March 2014 to March 2015. Depending on the wind direction, the T3 site experienced conditions ranging from nearly natural to heavily polluted. More detailed characterizations of aerosol- and gas-phase chemical composition were carried out at the T3 site during Intensive Operating Periods (IOPs) from 1 February 2014 to 31 March 2014 and from 15 August 2014 to 15 October 2014. In addition, data from two sites normally upwind of Manaus are also used in this study. These background sites include the T0a site (ATTO; $2^{\circ} 8^{\prime} 47.88^{\prime \prime} \mathrm{S}$, $59^{\circ} 0^{\prime} 18.00^{\prime \prime} \mathrm{W}$; Andreae et al., 2015) and the T0 $\mathrm{t}$ site $\left(2.6091^{\circ} \mathrm{S}, 60.2093^{\circ} \mathrm{W}\right.$; Martin et al., 2010a).

\subsection{Activated fraction of size-selected particles}

The CCN activation fraction of size-selected particles was measured using a differential mobility analyzer (DMA) coupled to a condensation particle counter (CPC; TSI Inc., 3010) and a cloud condensation nuclei counter (CCNC; Droplet Measurement Technologies, Boulder, CO; Frank et al., 2006; Mei et al., 2013a; Moore et al., 2010; Petters et al., 2007). Aerosol particles were sampled with a total flow rate $\left(Q_{\mathrm{a}}\right)$ of $1.53 \mathrm{~L} \mathrm{~min}^{-1}$ from a height of $5 \mathrm{ma}$ a.g.l. and were dried to relative humidity (RH) below $20 \%$ by a Nafion dryer immediately upon entering the instrument container. The dried 
aerosol particles then reached steady state charge distribution inside a $\mathrm{Kr}-85$ aerosol charger (TSI, model 3077A) prior to being introduced into the DMA operated with a sheath flow rate $\left(Q_{\mathrm{sh}}\right)$ of $15.3 \mathrm{~L} \mathrm{~min}^{-1}$ to maintain a $10: 1$ sheath to aerosol flow ratio $\left(Q_{\mathrm{sh}} / Q_{\mathrm{a}}\right)$. The aerosol particles were size-selected by the DMA, and the size-selected particles were simultaneously characterized by a CPC $\left(Q_{\mathrm{CPC}}=\right.$ $0.53 \mathrm{~L} \mathrm{~min}^{-1}$ ) and a CCNC (see Fig. S1 in the Supplement for further details). This system had been operated in previous field campaigns by scanning the particle size while CCNC supersaturation was held constant (Mei et al., 2013a, b). During GoAmazon2014/5 the particle size classified by the DMA was stepped through seven particle diameters (51, $75,94,112,142,171$, and $222 \mathrm{~nm}$ ), while the CCNC supersaturation was also changed at each diameter by stepping the flow rates $\left(Q_{\mathrm{CCN}}\right.$ ranging from 0.2 to $\left.1.0 \mathrm{~L} \mathrm{~min}^{-1}\right)$ and temperature gradient $\left(\Delta T=4.5,5.5,6.5,8.0\right.$, and $\left.10.0^{\circ} \mathrm{C}\right)$. At a given supersaturation, data were acquired for a minimum of $30 \mathrm{~s}$ and until 1500 particles were counted by the CPC or up to a maximum time of $120 \mathrm{~s}$. Depending on the aerosol number size distribution, the measurement cycled through the seven particle sizes in 1-2h (see Figs. S1 and S2 for further details of the measurement setup and sampling protocol). The sampling sequence was designed so that the change of CCNC supersaturation was mostly accomplished by stepping flow rates, as the CCNC reaches steady state faster following flow changes than temperature changes. Change in the temperature gradient was kept at a minimum frequency but was necessary given the wide range of supersaturation explored. Given the low particle number concentration (e.g., $\sim 200 \mathrm{~cm}^{-3}$ under background conditions during the wet season), these approaches were important to achieve adequate counting statistics with good time resolution to capture changes of air mass within 10-20 min (Liu et al., 2016). The supersaturation of the CCNC was calibrated using ammonium sulfate aerosol, as described previously in the literature (e.g., Mei et al., 2013a), at each operational set point ( $Q_{\mathrm{CCN}}$ and $\Delta T$ ), ranging from $0.075-1.1 \%$. Fluctuation of the temperature inside the instrument container, ranging from 20 to $30^{\circ} \mathrm{C}$ over the course of a day, led to substantial variation in the absolute temperature inside the CCNC growth chamber. Calibrations were therefore repeated under a range of container and associated-growth-chamber temperatures. The dependence of the supersaturation on the temperature at the top of the CCNC column (instrument temperature $T_{1}$ ) was derived for each $Q_{\mathrm{CCN}}$ and $\Delta T$ pair and used to retrieve the supersaturation over the range of the instrument operating conditions (see Fig. S3 and further description in the Supplement).

\subsection{Aerosol chemical composition}

Non-refractory submicron aerosol composition (organics, sulfate, nitrate, ammonium, and chloride) was measured by a high-resolution time-of-flight aerosol mass spectrometer
(HR-ToF-AMS; Aerodyne Research Inc.; DeCarlo et al., 2006) during the two IOPs and by an Aerosol Chemical Speciation Monitor (ACSM; Aerodyne Research, Inc.; Ng et al., 2011) from July 2014 to March 2015. The AMS sampled from an inlet equipped with a $\mathrm{PM}_{2.5}$ cyclone located at 5 ma.g.l. The ambient sample was first dried outside the container by a polytube Nafion dryer (Perma Pure, model PD-100T). Once inside the container the sample was further dried by a monotube Nafion dryer (Perma Pure, model MD-110) to achieve RH $<40 \%$ and was split between the AMS and a Scanning Mobility Particle Sizer (SMPS, TSI, model 3081). Ambient measurements were obtained every 4 of 8 min. Further details of the AMS setup and operation are described in de Sá et al. (2017a).

The ACSM was a part of the Atmospheric Radiation Measurement (ARM) Mobile Facility-1 (AMF1) mobile aerosol observing system (MAOS). Aerosol was sampled through an inlet located $10 \mathrm{~m}$ above the ground. The aerosol sample was first dried through five large $(40 \times 1.75 \mathrm{~cm}$ I.D. $)$ Nafion dryers before being distributed among various instruments including the ACSM. The ACSM sampling alternated between with and without an in-line filter using a three-way valve, such that aerosol-free background could be subtracted from the ambient measurement. A total of 28 ambient and background scans of the quadrupole mass spectrometer (unit mass resolution) were averaged to give one measurement every $30 \mathrm{~min}$. The mass concentrations of organic species, sulfate, nitrate, ammonium, and chloride were derived from measurements using approaches described in $\mathrm{Ng}$ et al. (2011).

Refractory black carbon (rBC) was measured using both a Single Particle Soot Photometer (SP2; Droplet Measurement Technologies, Boulder, $\mathrm{CO}$ ) and an aethalometer (Magee Scientific) co-located with the AMS and ACSM. The SP2 measures rBC using laser-induced incandescence, whereas the aethalometer measures equivalent black carbon $\left(\mathrm{BC}_{\mathrm{e}}\right.$; Andreae and Gelencsér, 2006) using light absorption from particles collected onto a filter. While these are fundamentally different aerosol properties, both species ( $\mathrm{rBC}$ and $\mathrm{BC}_{\mathrm{e}}$ ) were treated as equivalent in this study, and $\mathrm{BC}_{\mathrm{e}}$ concentration was adjusted to match that of $\mathrm{rBC}$ using the approach detailed in Sect. 2.2 of the Supplement.

\subsection{Additional relevant measurements}

Additional measurements of aerosol microphysics, trace gas concentrations, and atmospheric conditions used in this study are briefly described here. These measurements were part of the deployment of the ARM AMF1 facility during GoAmazon2014/5 (Martin et al., 2016). Relevant aerosol measurements include dry-particle number size distributions from 10 to $480 \mathrm{~nm}$ by an SMPS and the number concentration of particles with diameters greater than $10 \mathrm{~nm}$ by a CPC (TSI Inc., model 3772). Mixing ratios of $\mathrm{CO}$ and $\mathrm{O}_{3}$ were characterized by an Off-Axis Integrated Cavity Output Spectroscopy $\mathrm{CO}, \mathrm{N}_{2} \mathrm{O}$, and $\mathrm{H}_{2} \mathrm{O}$ analyzer (model number 908 - 
0014, Los Gatos) and a UV Photometric $\mathrm{O}_{3}$ analyzer (model 49i, Thermo Scientific Inc.), respectively. Oxides of nitrogen $\left(\mathrm{NO}, \mathrm{NO}_{x}, \mathrm{NO}_{2}, \mathrm{NO}_{y}\right.$ ) were measured using a chemiluminescence technique (details given in Sect. S2.1 of the Supplement). Meteorological data included relative humidity, ambient temperature, wind speed and direction, and rain accumulation. The vertical profiles of atmospheric backscatter (clouds and aerosol) and boundary layer heights were estimated from ceilometer (model CL31, Vaisala) measurements.

\section{Methods}

\subsection{Derivation of particle hygroscopicity and mixing state}

The particle hygroscopicity parameter, $\kappa$ (Petters and Kreidenweis, 2007), was derived from the activation spectrum (i.e., activated fraction as a function of supersaturation $S$ ) at the individual particle sizes using approaches detailed in the literature (Bougiatioti et al., 2011; Cerully et al., 2011; Lance et al., 2013; Mei et al., 2013a; Rose et al., 2008). The activation spectrum of size-selected particles was first corrected for the influence of multiply charged particles, which is estimated using the size distribution measured by the SMPS in MAOS and the activation spectrum measured at the sizes of the doubly and triply charged particles (see Sect. S3.1). The corrected activation spectrum of size-selected particles was then fit with a cumulative lognormal (Mei et al., 2013a; Rose et al., 2008) functional form (see Fig. S6 for examples):

$R_{\mathrm{a}}(S)=\frac{E}{2}\left[1+\operatorname{erf}\left(\frac{\ln S-\ln S^{*}}{\sqrt{2 \sigma_{\mathrm{s}}^{2}}}\right)\right]$,

where $R_{\mathrm{a}}$ is the activated fraction as a function of supersaturation $S, E$ is maximum activated fraction, and $(1-E)$ represents the number fraction of particles consisting of only nonhygroscopic species (e.g., uncoated rBC) that cannot serve as $\mathrm{CCN}$ under typical atmospheric supersaturations. $S^{*}$ is the supersaturation at which $R_{\mathrm{a}}$ reaches $50 \%$ of $E$ and represents the median critical supersaturation of size-selected particles that serve as $\mathrm{CCN}$. The value of $\sigma_{\mathrm{s}}$ is related to the slope of the increasing $R_{\mathrm{a}}$ with $S$ near $S^{*}$ and reflects the heterogeneity of critical supersaturation, which to a large degree arises from the heterogeneity of the hygroscopicity among size-selected particles (Cerully et al., 2011; Mei et al., 2013a). The probability density function of hygroscopicity for size-selected particles is derived from the $R_{\mathrm{a}}(S)$. The average hygroscopicity $\bar{\kappa}_{\mathrm{CCN}}$ and dispersion of the hygroscopicity $\sigma(\kappa) / \bar{\kappa}_{\mathrm{CCN}}$ for the size-selected $\mathrm{CCN}$ were then derived from the probability density function of hygroscopicity using the approach detailed in Sect. S3.4 in Supplement. The dispersion of the hygroscopicity reflects the composition heterogeneity (i.e., mixing state) among size-selected particles (Mei et al., 2013a). For simplicity, we use $\kappa_{\mathrm{CCN}}$ to represent the average hygroscopicity of size-selected $\mathrm{CCN}$ in the following sections. As hygroscopicities reported in this study were derived from particle dry diameter and critical supersaturation, they represent "apparent hygroscopicity", which includes the potential impact due to the limited solubility of organics and the reduction of surface tension by surface active species (Sullivan et al., 2009).

\subsection{Derivation of organic aerosol hygroscopicity}

The average particle hygroscopicity was then combined with the chemical composition data to derive the hygroscopicity of the organic component of the size-selected particles, $\kappa_{\text {org }}$. Collectively, the AMS, ACSM, SP2, and aethalometer provided mass concentrations of organic species, sulfate, nitrate, ammonium, and $\mathrm{rBC}$. The concentration of chloride was negligible ( $\gg 1 \%$ of aerosol mass) and was not included in the analysis. Given the low concentrations during GoAmazon2014/5, size-resolved mass concentrations at the time resolution of the $\mathrm{CCN}$ measurement were not directly derived from AMS particle-time-of-flight (PToF) mode data. For IOP1, measurements were classified into three groups based on bulk organic mass fraction and the characteristic mass size distribution of each species was averaged from measurements in each group. For the dry season, the measurements were classified into three groups each for day and night periods based on the bulk aerosol organic mass fraction, and the mass size distribution of each species was averaged from measurements in each of the six groups. The size-resolved mass concentrations of sulfate, nitrate, and organics at the time resolution of the $\mathrm{CCN}$ measurement were then derived by scaling the total mass concentration using the average mass size distributions for the corresponding group (based on the bulk organic mass fraction) of either wet or dry season (de Sá et al., 2017b). The shape of the $\mathrm{NH}_{4}^{+}$mass size distribution was assumed to be the same as that of sulfate, as ammonium cations were primarily associated with sulfate. rBC was assumed to have the same size distribution shape as the total aerosol mass (i.e., mass fraction of $\mathrm{rBC}$ was independent of particle size); though this assumption may not always be appropriate, the effect is expected to be very small as the monthly average volume fraction of $\mathrm{rBC}$ was always less than $4 \%$ (Fig. 1). A detailed description of the derivation of the size-resolved mass concentrations is given in Sect. S4.1.

In most cases, $\mathrm{NH}_{4}^{+}$was insufficient to completely neutralize $\mathrm{SO}_{4}^{2-}$. The concentrations of both the organonitrate and inorganic nitrate during the two IOPs were retrieved from AMS data based on the ratio of ions $\mathrm{NO}^{+}$and $\mathrm{NO}_{2}^{+}$(de Sá et al., 2017b; Fry et al., 2009). When the inorganic nitrate mass concentration was negligible (i.e., less than $30 \mathrm{ng} \mathrm{m}^{-3}$ ), as in most of the cases, the contributions of ammonium sulfate and ammonium bisulfate were calculated based on the mass concentrations of $\mathrm{SO}_{4}^{2-}$ and $\mathrm{NH}_{4}^{+}$(Nenes et al., 1998). In rare cases when the mass concentration of inorganic nitrate was greater than $30 \mathrm{ng} \mathrm{m}^{-3}$, sulfate was as- 

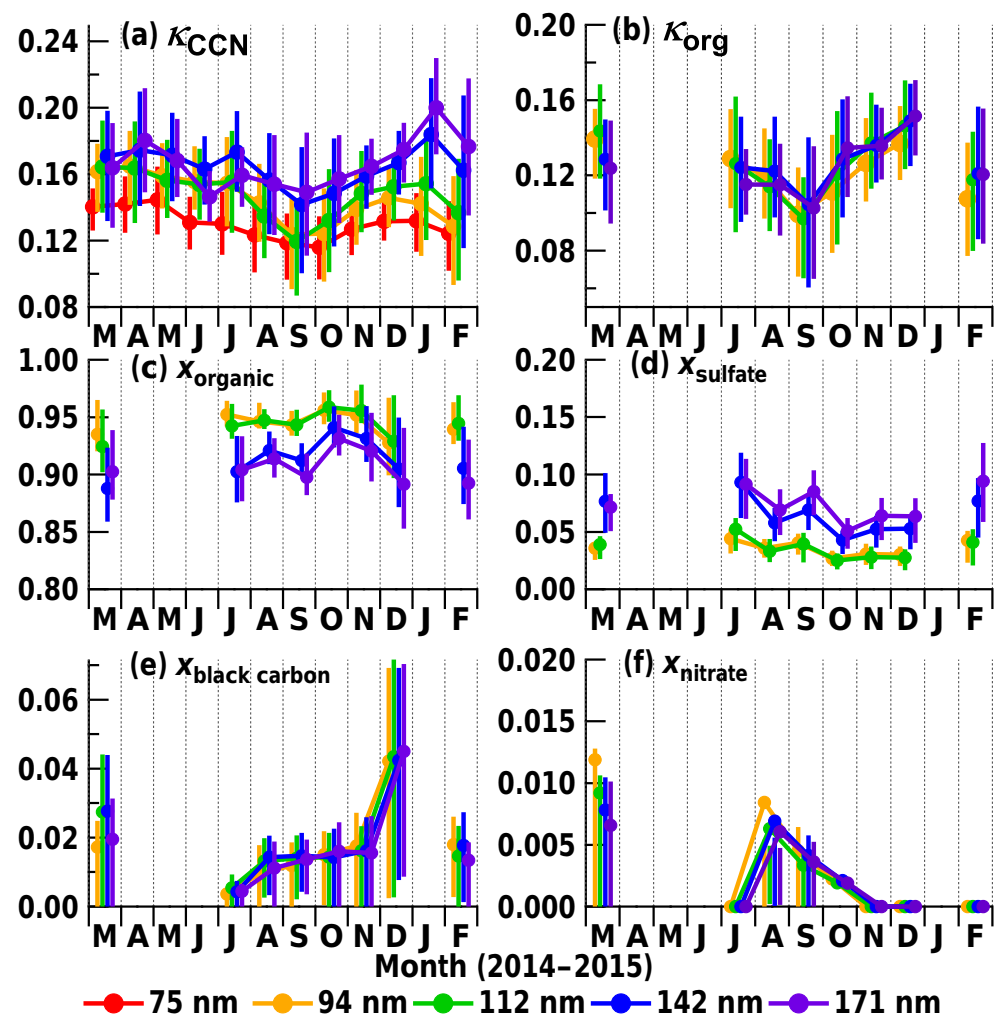

Figure 1. Seasonal variations of aerosol properties observed at the T3 site from March 2014 to March 2015, including (a) $\kappa_{\mathrm{CCN}}$; (b) $\kappa_{\mathrm{org}}$; and the size-resolved volume fraction of (c) organics; (d) sulfate, including $\left(\mathrm{NH}_{4}\right)_{2} \mathrm{SO}_{4}$ and $\mathrm{NH}_{4} \mathrm{HSO}_{4}$; (f) refractory black carbon; and (e) nitrate. Data points are the monthly mean; error bars represent the 25 th and 75 th percentiles.

sumed to be ammonium sulfate. During non-IOP periods, only the total nitrate mass concentration is available, all nitrate was assumed to be an organonitrate (Cerully et al., 2015; Lathem et al., 2013; Nenes et al., 1998; Zhang et al., 2005), and sulfate was fully neutralized by ammonium (see Sect. S4.2 in the Supplement for a sensitivity study of these assumptions for non-IOP periods). The $-\mathrm{ONO}_{2}$ portion of the organonitrate was added back to the organic mass. We note that the amount of $-\mathrm{ONO}_{2}$ added back was typically small given the low mass fraction of nitrate in the aerosol. Cloud condensation nuclei were assumed to be internal mixtures of $\left(\mathrm{NH}_{4}\right)_{2} \mathrm{SO}_{4}, \mathrm{NH}_{4} \mathrm{HSO}_{4}, \mathrm{NH}_{4} \mathrm{NO}_{3}$, organics, and $\mathrm{rBC}$, and the volume fractions of the species were derived from the mass concentrations and densities. Densities of organics were estimated from the ratios of $\mathrm{O}: \mathrm{C}$ and $\mathrm{H}: \mathrm{C}$ measured by the AMS (Kuwata et al., 2012) and were on average $1450 \pm 100$ and $1470 \pm 80 \mathrm{~kg} \mathrm{~m}^{-3}$ for IOP1 and IOP2, respectively. Densities of $1770,1790,1730$, and $1800 \mathrm{~kg} \mathrm{~m}^{-3}$ were used for $\left(\mathrm{NH}_{4}\right)_{2} \mathrm{SO}_{4}, \mathrm{NH}_{4} \mathrm{HSO}_{4}, \mathrm{NH}_{4} \mathrm{NO}_{3}$, and $\mathrm{rBC}$ (Bond and Bergstrom, 2006; Park et al., 2004), respectively. In very rare cases, $E$ was less than $100 \%$, suggesting some of the size-selected particles were nonhygroscopic. The nonhygroscopic particles were assumed to consist entirely of $\mathrm{rBC}$ (Mei et al., 2013a). The volume concentration of the nonhygro- scopic particles was derived as the product of $(1-E)$ and the total volume concentration (i.e., the sum of volume concentrations of organics, $\left(\mathrm{NH}_{4}\right)_{2} \mathrm{SO}_{4}, \mathrm{NH}_{4} \mathrm{HSO}_{4}, \mathrm{NH}_{4} \mathrm{NO}_{3}$, and $\mathrm{rBCs}$ ) at the size classified by the DMA. The volume concentration of $\mathrm{rBC}$ internally mixed within the $\mathrm{CCN}$-active particles was then calculated as the difference between the total $\mathrm{rBC}$ volume concentration and the volume concentration of the nonhygroscopic particles. (Mei et al., 2013a, b). Assuming a $\kappa$ value of zero for $\mathrm{rBC}$, we can derive the hygroscopicity of the organic component of the $\mathrm{CCN} \kappa_{\text {org }}$ as

$$
\begin{aligned}
& \kappa_{\text {org }}=\frac{1}{x_{\text {org }}}\left(\kappa_{\mathrm{CCN}}-x_{\left(\mathrm{NH}_{4}\right)_{2} \mathrm{SO}_{4}} \kappa_{\left(\mathrm{NH}_{4}\right)_{2} \mathrm{SO}_{4}}\right. \\
& \left.-x_{\mathrm{NH}_{4} \mathrm{HSO}_{4}} \kappa \mathrm{NH}_{4} \mathrm{HSO}_{4}-x_{\mathrm{NH}_{4} \mathrm{NO}_{3}} \kappa_{\mathrm{NH}_{4} \mathrm{NO}_{3}}\right) \text {, }
\end{aligned}
$$

where $x_{i}$ is the volume fraction of the respective species. The $\kappa$ values are $0.61,0.7$, and 0.67 for $\left(\mathrm{NH}_{4}\right)_{2} \mathrm{SO}_{4}, \mathrm{NH}_{4} \mathrm{HSO}_{4}$, and $\mathrm{NH}_{4} \mathrm{NO}_{3}$, respectively (Petters and Kreidenweis, 2007). The uncertainty in $\kappa_{\text {org }}$ using these calculations has been derived using the approach detailed in earlier studies (Mei et al., $2013 \mathrm{a}, \mathrm{b}$ ) and is on the order of $0.01-0.02$ (which was generally between 10 and $20 \%$ ) for this dataset. 


\subsubsection{Derivation of $\kappa$ for AMS PMF factors}

PMF was applied to the AMS mass spectra (Lanz et al., 2008; Ulbrich et al., 2009), and six organic factors were identified for each of the two IOPs (de Sá et al., 2017b). For IOP2 the PMF analysis included data from 24 August to 15 October 2014, excluding a major regional biomass burning event from 16 to 23 August, which was treated separately in the PMF analysis. For IOP1 (wet season), the six factors were isoprene-epoxydiol-derived secondary organic aerosol (IEPOX-SOA), more-oxidized oxygenated organic aerosol (MO-OOA, i.e., highly oxidized organics), less-oxidized oxygenated organic aerosol (LO-OOA), biomass burning organic aerosol (BBOA) with characteristic peaks at $m / z=60$ and 73 and correlated with the concentrations of levoglucosan and vanillin, a factor with high contribution from $m / z=91$ (Fac91) and correlated with anthropogenic emissions of aromatics, and hydrocarbon-like organic aerosol (HOA). The six factors for IOP2 included IEPOX-SOA, MOOOA, LO-OOA, an aged biomass burning organic aerosol factor (aged BBOA), a fresh biomass burning organic aerosol factor (fresh BBOA), and HOA. Further details of PMF analysis and the characteristics of the factors can be found in de Sá et al. (2017b). The O:C ratio and calculated density for each factor are presented in Table 1. In this study, the $\mathrm{O}: \mathrm{C}$ ratio was derived using the Improved-Ambient method (Canagaratna et al., 2015).

For each IOP, hygroscopicities associated with the six factors were attributed based on multilinear regression of $\kappa_{\text {org }}$ with respect to the volume fractions of the factors (Levenberg-Marquardt algorithm, IGOR Pro, Wavemetrics):

$\kappa_{\mathrm{org}}=\sum_{i}^{n} \kappa_{i} x_{i}$,

where $\kappa_{i}$ and $x_{i}$ are the hygroscopicity and volume fraction of the individual organic PMF factors. The volume fraction was derived from mass concentrations and the densities of the factors. $\kappa_{\text {org }}$ represents the average organic hygroscopicity at particle diameters $\left(D_{\mathrm{p}}\right)$ of 142 and $171 \mathrm{~nm}$. As the PMF analysis is based on the mass spectra of the bulk submicrometer aerosol (i.e., MS mode measurements), an implicit assumption of Eq. (3) is that the bulk volume fractions of the factors represented those over the sizes at which $\kappa_{\text {org }}$ was derived (i.e., $D_{\mathrm{p}}=142$ and $171 \mathrm{~nm}$ ). The validity of this assumption is discussed in the results section. The robustness of the factor hygroscopicity derived through linear regression depends on the variation of the factor volume fraction during the measurement period. The HOA hygroscopicity was assumed as zero based on the results from previous studies (Cappa et al., 2009, 2011; Jimenez et al., 2009), and the hygroscopicity of the other five factors were derived by multilinear regression as described above.

\subsection{Classification of seasons and air masses}

The 1-year sampling period was divided into different seasons by grouping months according to the similarity of the aerosol properties and trace gas concentrations measured at the two background sites, T0a and T0t, as well as monthly accumulated rainfall. In this study, the seasons were defined as follows: the first wet season - March, April, and May of 2014; the first transition season - June and July 2014; the dry season - August and September of 2014; the second transition season - October, November, and the first half of December 2014; and the second wet season - the second half of December 2014 and January, February, and the first few days of March 2015.

For each season, the air masses arriving at the T3 site were classified into three different types: background, urban pollution, and local biomass burning based on trace gas and aerosol measurements at all sites. During the wet season, the background air mass represented near-natural conditions, with occasional impact from anthropogenic emissions, while, in the dry season, the background was dominated by regional biomass burning aerosol particles. Polluted air masses represent those with strong influence from urban emissions, which were mostly from Manaus. The localbiomass-burning type describes those air masses strongly influenced by local (i.e., fresh) biomass burning activities, which dominated over the impact from urban pollution, if any. For each season, background conditions were identified when $\mathrm{CO}$ and condensation nuclei $(\mathrm{CN})$ concentrations were below the thresholds derived from measurements at the background $\mathrm{T} 0 \mathrm{a}$ and $\mathrm{T} 0 \mathrm{t}$ sites, and the $\mathrm{NO}_{y}$ mixing ratio was below $1.5 \mathrm{ppb}$. Non-background conditions were identified by condensation nuclei and $\mathrm{CO}$ concentrations above the respective threshold levels. As biomass burning aerosol typically has a higher fraction of accumulation-mode particles, and the emissions from Manaus were more dominated by Aitken-mode particles, the fraction of particles with diameter less than $70 \mathrm{~nm}$ was used to differentiate air masses strongly influenced by local biomass burning from those with more impact from urban pollution (see Table S2 in Supplement for details). Contamination by the emissions from an on-site diesel generator, grass cutting activities, tractors, and other vehicles were evidenced by $\mathrm{rBC}$ concentrations above $1.0 \mu \mathrm{g} \mathrm{m}^{-3}$ or $\mathrm{CN}$ concentration above $10000 \mathrm{~cm}^{-3}$. Over the 1-year measurement period, background, urban pollution, and local biomass burning represented $12.4,38.5$, and $28.4 \%$ of the CCN measurements, respectively (Table S3). We note that the air masses arriving at the T3 site often included contributions from different sources. The classification of the air masses using the above three types clearly represents a simplification but is very helpful for understanding the properties of aerosols influenced by the various major sources. 
Table 1. Density, O : C ratio, and hygroscopicity associated with organic factors derived from positive matrix factorization (PMF) analysis. For IOP1 and IOP2, hygroscopicities of PMF organic factors were derived from time series of particle hygroscopicity under all conditions and background conditions, respectively.

\begin{tabular}{llll|llll}
\hline \multicolumn{3}{c}{ IOP1 (wet season) } & \multicolumn{3}{c}{ IOP2 (dry season) } \\
\hline PMF factor & $\rho\left(\mathrm{g} \mathrm{cm}^{-3}\right)$ & $\mathrm{O}: \mathrm{C}$ & $\kappa$ & PMF factor & $\rho\left(\mathrm{g} \mathrm{cm}^{-3}\right)$ & $\mathrm{O}: \mathrm{C}$ & $\kappa(\mathrm{Bkgd})^{*}$ \\
\hline IEPOX-SOA & 1.47 & 0.798 & $0.18 \pm 0.02$ & IEPOX-SOA & 1.42 & 0.711 & $0.08 \pm 0.03$ \\
MO-OOA & 1.80 & 1.19 & $0.20 \pm 0.02$ & MO-OOA & 1.81 & 1.24 & $0.21 \pm 0.03$ \\
LO-OOA & 1.48 & 0.786 & $0.12 \pm 0.02$ & LO-OOA & 1.52 & 0.883 & $0.20 \pm 0.03$ \\
BBOA & 1.42 & 0.712 & $0.04 \pm 0.03$ & Aged BBOA & 1.37 & 0.666 & $0.08 \pm 0.03$ \\
Fac91 & 1.14 & 0.328 & $0.10 \pm 0.03$ & Fresh BBOA & 1.23 & 0.536 & $0.00 \pm 0.07$ \\
HOA & 0.95 & 0.163 & 0 & HOA & 1.02 & 0.223 & 0 \\
\hline
\end{tabular}

$* \kappa$ (Bkgd) refers to $\kappa$ values of PMF factors derived from the time series of particle hygroscopicity under background conditions (see Sects. 4.2.2 and 4.3).

\section{Results}

\subsection{Seasonal trend and size dependence of hygroscopicity and chemical composition}

The monthly average $\kappa_{\mathrm{CCN}}$ at the $\mathrm{T} 3$ site varied from 0.1 to 0.2 at five particle diameters ranging from 75 to $171 \mathrm{~nm}$ (Fig. 1a) and was substantially lower than the value of $0.3 \pm$ 0.1 suggested for continental sites (Andreae and Rosenfeld, 2008). This was due to the large organic volume fraction, up to $95 \%$, observed at the T3 site. In this study, measurements at 51 and $222 \mathrm{~nm}$ were not included, because the range of supersaturation sampled inside the CCN counter only adequately captured the activation spectrum for $51 / 222 \mathrm{~nm}$ particles with relatively high/low $\kappa_{\mathrm{CCN}}$ values, leading to a positive/negative bias of the average $\kappa_{\mathrm{CCN}}$. The value of $\kappa_{\mathrm{CCN}}$ exhibited similar seasonal variations at all five sizes. During the transition from wet to dry season, $\kappa_{\mathrm{CCN}}$ decreased by $20-$ $30 \%$ with the absolute minimum of 0.116 occurring at $75 \mathrm{~nm}$ in September and October (Fig. 1a).

The seasonal trend of $\kappa_{\mathrm{CCN}}$ was mainly driven by the variation of $\kappa_{\text {org }}$, which shows the lowest value in September during the dry season (Fig. 1b). Despite a strong increase in aerosol mass concentration from wet to dry season due to biomass burning emissions, the organic volume fraction exhibited little seasonal variation and was $\sim 90 \%$ or higher at the four sizes from 94 to $171 \mathrm{~nm}$ (Fig. 1c). A minor increase in organic volume fraction in October might have also contributed to the lower $\kappa_{\mathrm{CCN}}$ value observed. The species volume fractions at $75 \mathrm{~nm}$ are not shown due to the very low signal-to-noise ratio of the AMS PToF data in the small particle diameter range. No clear seasonal trend was observed for sulfate volume fraction, which ranged from 3 to $9 \%$ at the four sizes. The lack of clear seasonal trends of sulfate and organic fractions is consistent with observations at the T0a site (Andreae et al., 2015). Nitrate and rBC represented a small fraction of aerosol volume and were less than 1 and $\sim 4 \%$, respectively.
The average $\kappa_{\mathrm{CCN}}$ increased with increasing particle size for all three air mass types and during all the seasons (Fig. 2), consistent with decreasing organic volume fraction with increasing particle size (Fig. 1c). The $\kappa_{\mathrm{CCN}}$ at $75,94,112$, 142 , and $171 \mathrm{~nm}$ averaged for the 1-year measurement period were $0.130 \pm 0.028,0.144 \pm 0.039,0.148 \pm 0.043,0.164 \pm$ 0.046 , and $0.167 \pm 0.042$, respectively. The value of $\kappa_{\mathrm{CCN}}$ and its size dependence under background conditions were largely consistent among different seasons and were in good agreement with those observed under near-natural conditions during the AMAZE-08 campaign at T0t in the wet season (Gunthe et al., 2009) and during the 1-year period from March 2014 to February 2015 at the background T0a site (Pöhlker et al., 2016). For the air masses with strong influence from local biomass burning, the value of $\kappa_{\mathrm{CCN}}$ and its size dependence are consistent with the $\kappa$ value derived from particle growth factor measurements in July 2001, during a "recent biomass burning period" of the CLAIRE-2001 study (Rissler et al., 2004), which took place at Balbina, about $125 \mathrm{~km}$ northeast of Manaus. In contrast, $\kappa$ values derived from particle growth factor measurements from 11 September to 8 October 2002, during the dry period of the LBASMOCC (Rissler et al., 2006), are substantially lower than $\kappa_{\mathrm{CCN}}$ values observed at the T3 site for local biomass burning air masses at all sizes. As LBA-SMOCC took place in the state of Rondônia in southwestern Amazonia with extensive biomass burning activities during the dry season, the difference in $\kappa$ could be due to the differences in fire condition and the type of vegetation burned. Previous studies show particles sometime exhibit larger $\kappa$ values for droplet activation (derived from $\mathrm{CCN}$ measurements under supersaturated conditions) than for particle growth (derived from particle growth factor under subsaturated conditions); this could also contribute to the differences in $\kappa$ values. Compared to $\kappa_{\mathrm{CCN}}, \kappa_{\mathrm{org}}$ was largely independent of particle size for all three air mass types, indicating that the size dependence of $\kappa_{\mathrm{CCN}}$ was mainly due to the size dependence of the organic volume fraction and particle composition (Fig. 1c-f). Dur- 
ing the dry season, aerosols classified as urban pollution and local biomass burning exhibited lower $\kappa_{\text {org }}$ values compared to background aerosols, contributing to the lower values of overall $\kappa_{\mathrm{CCN}}$.

\subsection{Diel trends of particle and organic hygroscopicities}

The diel variations of aerosol properties are presented in Figs. 3-7 for different air masses during the two IOPs. Aerosol properties derived from the size-resolved $\mathrm{CCN}$ measurements, including $\kappa_{\mathrm{CCN}}, \sigma_{\kappa_{\mathrm{CCN}}} / \bar{\kappa}_{\mathrm{CCN}}$, and $\kappa_{\mathrm{org}}$, and the volume fractions of different species were averaged at the three largest sizes $\left(D_{\mathrm{p}}=112,142\right.$, and $\left.171 \mathrm{~nm}\right)$. The fraction of organic mass at $m / z=44\left(f_{44}\right)$ and $\mathrm{O}: \mathrm{C}$ were derived from the AMS bulk measurements. Also shown are diel variations of planetary boundary layer (PBL) height, $\mathrm{CN}$, and aerosol volume concentrations based on 5 min average data.

\subsubsection{Wet season aerosol}

\section{Background conditions}

Figures 3 and 4 show the diel variations of aerosol properties during the wet season of 2014 for background and urban pollution air masses, respectively. Only $0.7 \%$ of the data were classified as local biomass burning (see Table S3), which is insufficient to evaluate the diel trends. During the wet season, the background air mass represents near-natural conditions, with minimum impact from anthropogenic emissions, although long-distance transport of African biomass burning may contribute to the aerosols observed (Chen et al., 2009; Wang et al., 2016b). Background aerosol constantly exhibited relatively high hygroscopicity of $\sim 0.19$ throughout the day. The lack of a diel trend in $\kappa_{\mathrm{CCN}}$ is also in agreement with the results from the T0a site (ATTO), which is upwind of Manaus and served as a background site (Fig. 8). The particle composition averaged for the three particles diameters was dominated by organics, representing $\sim 90 \%$ of the aerosol volume. The lack of a diel trend in $\kappa_{\mathrm{CCN}}$ and $\kappa_{\mathrm{org}}$ suggests little variation in particle composition throughout the day. The nearly constant $\kappa_{\text {org }}$ of $\sim 0.16$ is also consistent with the lack of a diel trend in $f_{44}$ and $\mathrm{O}: \mathrm{C}$. The values of $f_{44}$ and $\mathrm{O}: \mathrm{C}$ are $\sim 0.2$ and $\sim 0.8$, respectively, indicating that the aerosol under background condition during the wet season was dominated by the aged regional aerosol particles consisting of highly oxygenated organic compounds.

Aerosol number and volume concentrations exhibited a minimum at $\sim 310 \mathrm{~cm}^{-3}$ and $\sim 0.3 \mu \mathrm{m}^{3} \mathrm{~cm}^{-3}$, respectively, just before sunrise. The number and volume concentrations started increasing after sunrise and peaking at $400 \mathrm{~cm}^{-3}$ and $0.8 \mu \mathrm{m}^{3} \mathrm{~cm}^{-3}$ in the afternoon. These diel variations are partially attributed to the wet scavenging of accumulation-mode particles, which dominate the submicron particle concentrations under background conditions, and the mixing of the particles from the residual layer aloft down to the surface as the boundary layer develops in the morning. During the night, the radiative cooling at the surface leads to a shallow nocturnal boundary layer with low and variable winds. RH near surface was near $100 \%$, and fog or mist was identified by the weather station (Present Weather Detector, Visalia) $62 \%$ of the time during the 1-year measurement period. The gradual decreases of particle number and volume concentration during these fog events were due to the wet deposition of the accumulation-mode particles activated into droplets. Similar decreases of particle number concentration were previously reported during night fog events in the tropical rainforest in Borneo (Whitehead et al., 2010). After sunrise, the boundary layer deepened on average from less than 200 up to $800 \mathrm{~m}$ as a result of solar heating (Fig. 3g). Consequently, particles in the residual layer aloft (Fisch et al., 2004; Rissler et al., 2006), which were not impacted by the fog, were mixed down to the surface, leading in part to the observed increases in both number and volume concentrations. Such mixing of particles from the residual layer in the morning had been observed previously in the Amazon basin during the dry season (Rissler et al., 2006). The formation of secondary organic aerosol (SOA) as a result of photochemical oxidation (in both gas and particle phases) likely contributed to the increase in volume concentration (Chen et al., 2015, 2009; Martin et al., 2010a; Pöschl et al., 2010).

\section{Air masses impacted by urban pollution}

Air masses arriving at the T3 site frequently had passed over urban and industrial areas upwind. When the air mass was influenced by the urban pollution, $\kappa_{\mathrm{CCN}}$ and its dispersion exhibited clear diel variations (Fig. 4). The value of $\kappa_{\mathrm{CCN}}$ was lower during the night at 0.15 , and it increased from the early morning hours, peaking at a value of 0.19 around noon (LT, UTC $-4 \mathrm{~h}$ ). The dispersion was anticorrelated with $\kappa_{\mathrm{CCN}}$, exhibiting higher values (i.e., increased heterogeneity in particle chemical composition) during night and a minimum value around noon. To a large degree, the diel trend of $\kappa_{\mathrm{CCN}}$ was due to the variation of $\kappa_{\mathrm{org}}$. The value of $\kappa_{\mathrm{org}}$ was lower during night at 0.10 and increased to 0.16 at noon. The increase in $\kappa_{\text {org }}$ is consistent with the variation of $\mathrm{O}: \mathrm{C}$, which increased during the early morning and reached the highest value of 0.8 around noon time. The pollution strongly affected the particle number and volume concentrations, both exhibiting similar diel trends. Under polluted conditions, particle number concentration ranged on average from 1500 to $2300 \mathrm{~cm}^{-3}$, which is an increase by a factor of $\sim 5$ from that under background conditions. In comparison, the increase in the volume concentration was only about a factor of 2 (i.e., from a range of $0.3-0.75$ to 1.0 to $1.3 \mu \mathrm{m}^{3} \mathrm{~cm}^{-3}$ ), as the urban pollution is dominated by Aitken-mode particles that make a relatively small contribution to aerosol mass and volume concentration.

The diel variations of $\kappa_{\mathrm{CCN}}$, its dispersion, $\kappa_{\mathrm{org}}$, and $\mathrm{O}: \mathrm{C}$ are explained as follows. During night, particles in freshly 

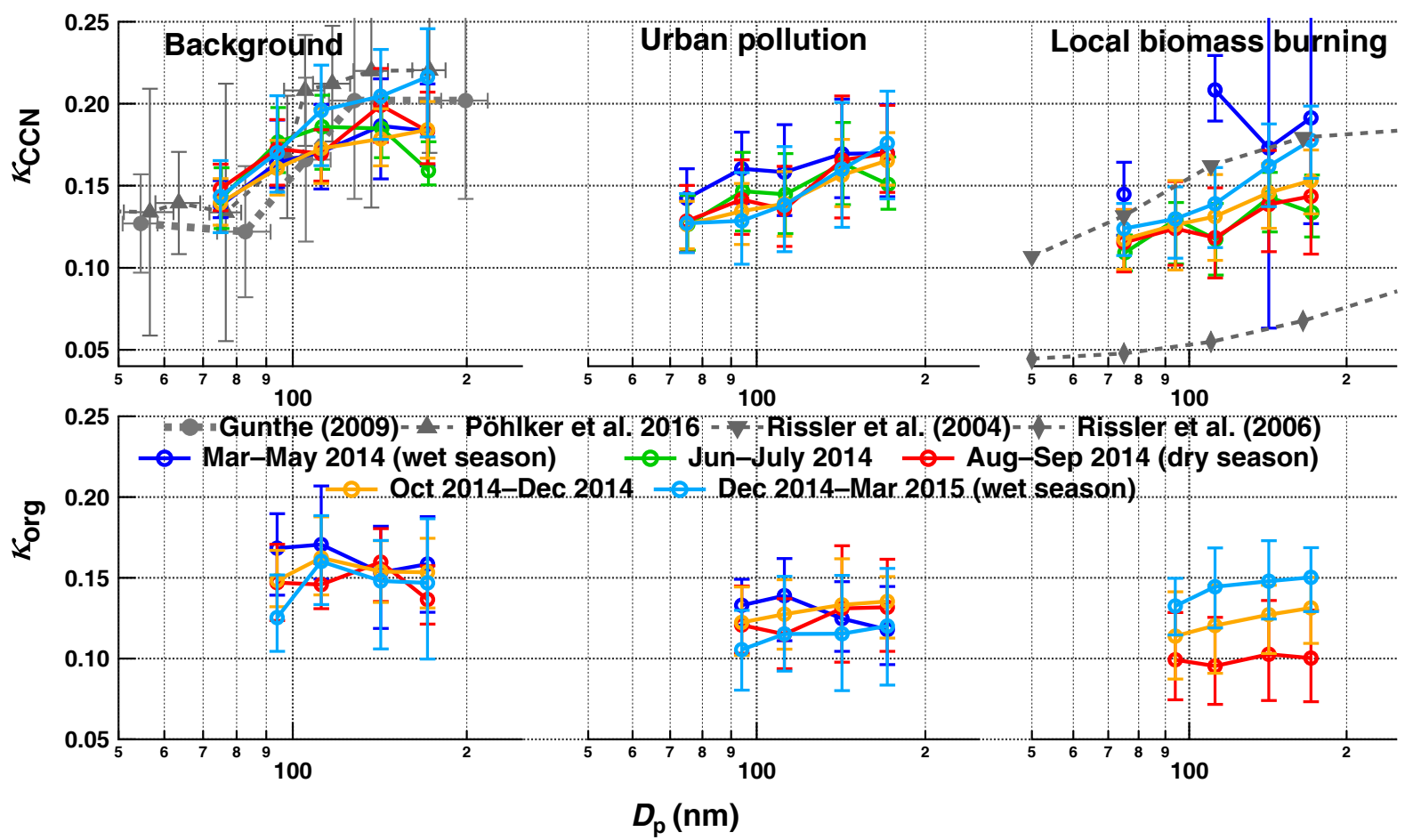

Figure 2. The variation of $\kappa_{\mathrm{CCN}}$ and $\kappa_{\mathrm{org}}$ with particle diameter during different seasons for each of three air mass types. Data points are the mean values; error bars are the 25 th and 75 th percentiles. The top-left panel also includes $\kappa_{\mathrm{CCN}}$ observed under near-natural conditions during the AMAZE-08 campaign at T0t in the wet season (Gunthe et al., 2009) and during the 1-year period from March 2014 to February 2015 at the background T0a site (Pöhlker et al., 2016). The top-right panel includes $\kappa$ derived from particle growth factor measurements in July 2001, during a "recent biomass burning period" of the CLAIRE-2001 study (Rissler et al., 2004), and from 11 September to 8 October 2002, during the dry period of the LBA-SMOCC (Rissler et al., 2006).

emitted pollution, which are dominated by primary organic aerosol (POA) and have low hygroscopicity, are mixed with more aged particles within a shallow nocturnal boundary layer (Bateman et al., 2017). In the absence of photochemical oxidation and aging, this external mixture leads to higher dispersion of particle hygroscopicity as well as overall lower $\mathrm{O}: \mathrm{C}$ and $\kappa_{\mathrm{org}}$. As the pollution aerosols are mainly from isolated point sources, they are confined in the shallow nocturnal boundary layer during night, and the residual layer above the T3 site is expected to consist of aged background aerosols. Therefore, unlike under background conditions, the mixing of aerosol aloft in the residual layer down to the surface cannot by itself explain the increase in particle number and volume concentration during the day, both of which were substantially above the background values. These increases under polluted conditions might be due to the stronger urban influence at T3 during the day. The strong increase in CN concentration at 16:00 UTC (12:00 LT) could be caused by the arrival at the T3 site of the Manaus plume emitted during early morning traffic hours. To a large degree, the increases in $\mathrm{O}: \mathrm{C}$ and $\kappa_{\text {org }}$ are due to the formation and aging of SOA in the pollution, while the development of the daytime boundary layer, which leads to dilution of pollution and mixing with aged particles from the residual layer, can also contribute to the increases. The condensation of secondary species and photochemical aging also leads to more homogenous composition among particles (Mei et al., 2013a), and therefore lower dispersion of $\kappa_{\mathrm{CCN}}$, as was observed. The $\mathrm{O}: \mathrm{C}$ reached a maximum average value of 0.8 , similar to that under the background conditions. This suggests that the formation and photochemical aging of SOA quickly led to highly oxygenated organic compounds (i.e., within several hours; de Sá et al., 2017b).

\subsubsection{Dry season aerosol}

\section{Background conditions}

Figures 5-7 show the diel variations of the aerosol properties observed during the dry season for background, urban pollution, and local biomass burning air masses, respectively. During the dry season, the background aerosol (Fig. 5) is strongly influenced by regional biomass burning, and air masses arriving at the $\mathrm{T} 3$ site often pass through urban and industrial areas along the Amazon River and in northeast Brazil (Andreae et al., 2015), indicating that the background aerosol is also impacted by more aged urban and industrial emissions 


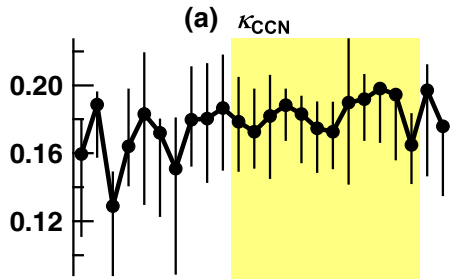

(d) $\kappa_{\text {org }}$

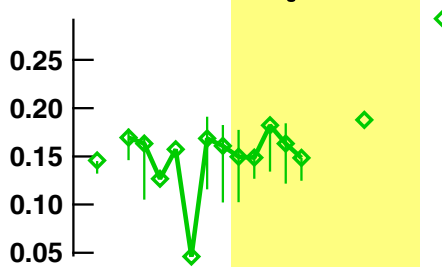

(g) PBL height (km)

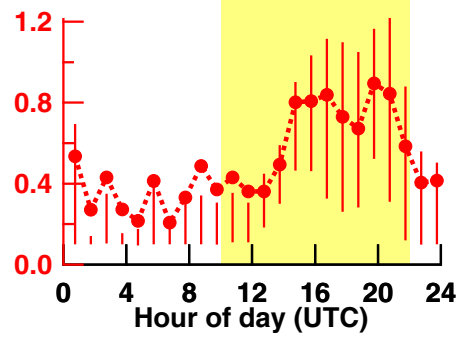

$\diamond$ (b)

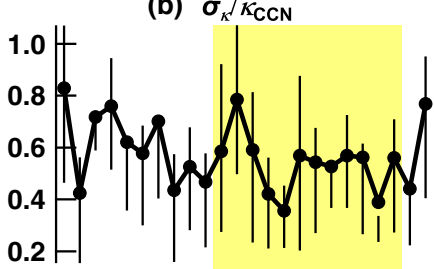

(e) $N_{\mathrm{CN}}\left(\mathrm{cm}^{-3}\right)$

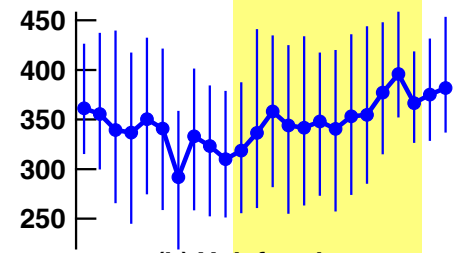

(h) Vol. fraction

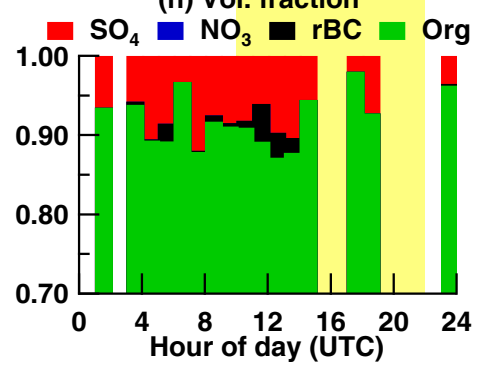

(c) $f_{44} ; 0: C$

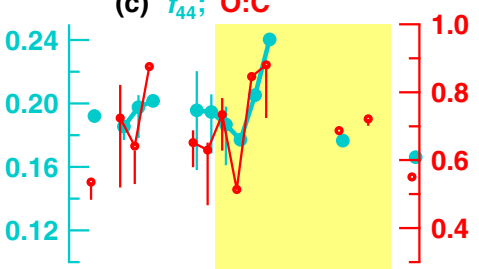

(f) Volume $\left(\mu \mathrm{m}^{3} \mathrm{~cm}^{-3}\right)$

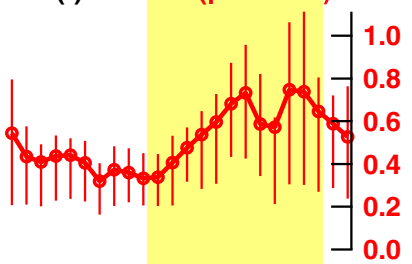

(i) No. of data points

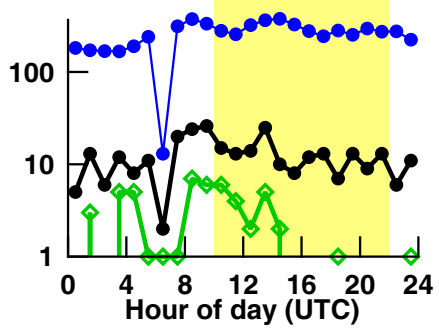

Wet season - background conditions

Figure 3. Diel variations of aerosol properties and meteorological parameters under background conditions during the wet season, including (a) $\kappa_{\mathrm{CCN}}$, (b) $\sigma_{\kappa_{\mathrm{CCN}}} / \bar{\kappa}_{\mathrm{CCN}}$, (c) fraction of the organic mass at $m / z=44\left(f_{44}\right)$ and the elemental ratio $\mathrm{O}: \mathrm{C}$, (d) $\kappa_{\mathrm{org}}$ derived using sizeresolved particle composition, (e) the total number of condensation nuclei $\left(N_{\mathrm{CN}}\right)$, (f) the total aerosol volume derived from size distribution measured by the SMPS in MAOS, (g) planetary boundary layer height as estimated using the ceilometer data, (h) the volume fractions of aerosol species, and (i) the number of samples in each hour bin corresponding to the data by the same colors and symbols in their respective panel. The values of $\kappa_{\mathrm{CCN}}, \sigma_{\kappa_{\mathrm{CCN}}} / \bar{\kappa}_{\mathrm{CCN}}, \kappa_{\mathrm{org}}$, and the volume fraction of aerosol species were averaged over three particle diameters of 112 , 142, and $171 \mathrm{~nm}$. The values of $f_{44}$ and $\mathrm{O}: \mathrm{C}$ were derived from the AMS bulk measurements. Data include the last 2 weeks of March 2014 when valid data from both size-resolved CCN system and AMS were available. Data points are hourly averaged mean values; error bars represent the 25th and 75th percentiles of the data. Yellow shading represents the local daytime (10:00-22:00 UTC).

(Martin et al., 2017). Despite different aerosol sources and processes, the particle hygroscopicity, dispersion, and $\kappa_{\text {org }}$ exhibited similar values as those of background aerosol during the wet seasons and a lack of obvious diel variations. This is also consistent with the absence of a significant diel trend of $\kappa_{\mathrm{CCN}}$ observed at T0a (ATTO) during the dry season (Fig. 8). The $\mathrm{O}: \mathrm{C}$ value increased slightly from 0.8 during night to 0.9 in the afternoon, possibly due to further oxidation and aging of background aerosols during the daytime. The high value of $\mathrm{O}: \mathrm{C}$ is consistent with the relatively high value of $\kappa_{\text {org }}(0.15)$ and is close to that observed under background condition during the wet season, indicating highly oxygenated organic aerosol. The number and volume concentrations were lower just before dawn and increased during the early morning, again a result of wet scavenging of particles by fog followed by the mixing of aerosol aloft in the residual layer down to the surface as the boundary layer develops in the morning.

\section{Air masses impacted by urban pollution and local biomass burning}

For urban pollution (Fig. 6) and local biomass burning (Fig. 7) air masses during the dry season, $\kappa_{\mathrm{CCN}}$ (urban pollution: $0.12-0.20$; local biomass burning: $0.10-0.17)$, its dispersion (urban pollution: $0.4-1.0$; local biomass burning: $0.4-0.9), \kappa_{\text {org }}$ (urban pollution: $0.10-0.15$; local biomass burning: 0.08-0.14), and $\mathrm{O}: \mathrm{C}$ (polluted: 0.7-0.85; biomass burning: 0.7-0.86) showed similar values and diel variations as those under polluted conditions during the wet season. This is consistent with the picture that freshly emitted particles (in either the case of urban pollution or local biomass burning) lead to overall lower $\mathrm{O}: \mathrm{C}, \kappa_{\mathrm{org}}$, and higher $\kappa_{\mathrm{CCN}}$ dispersion during night, followed by increases in $\mathrm{O}: \mathrm{C}$, $\kappa_{\text {org }}$, and a decrease in the dispersion during daytime, which are mainly driven by the formation and photochemical aging of SOA, with contributions from the mixing of background aerosol aloft in the residual layer down to the surface 
(a) $\kappa_{\mathrm{CCN}}$

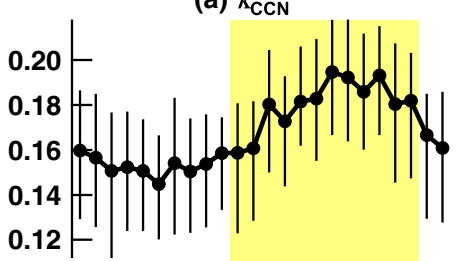

(d) $\kappa$ org

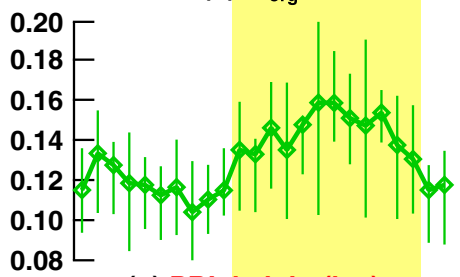

(g) PBL height (km)

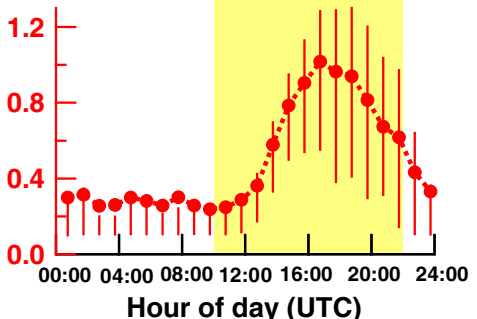

(b) $\sigma_{\kappa} / \kappa_{\mathrm{CCN}}$

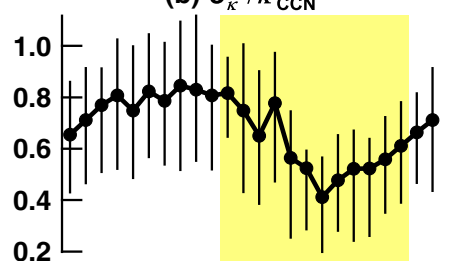

(e) $\mathrm{N}_{\mathrm{CN}}\left(\mathrm{cm}^{-3}\right)$

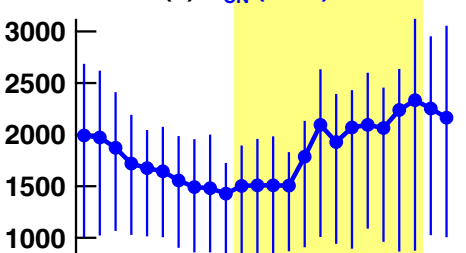

(h) Vol. fraction

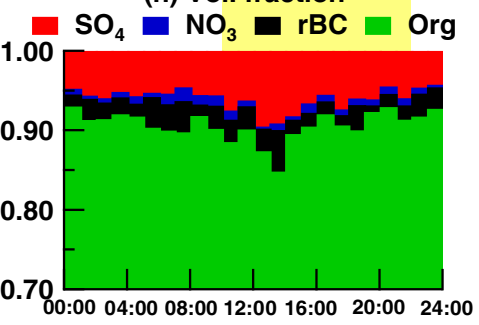

Hour of day (UTC)

Wet season - polluted conditions

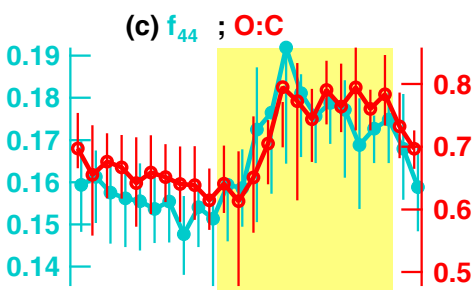

(f) Volume $\left(\mu \mathrm{m}^{3} \mathrm{~cm}^{-3}\right)$

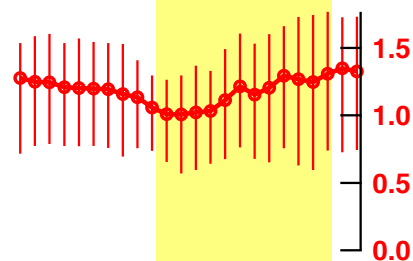

(i) No. of data points

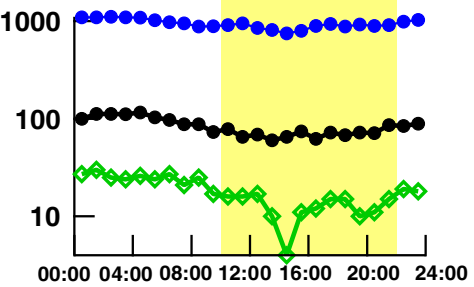

Hour of day (UTC)

Figure 4. Diel variations of aerosol properties and meteorological parameters for urban pollution air masses during the wet season (analogous to Fig. 3).

and dilution of fresh emission as the boundary layer develops. Compared to urban pollution, local biomass burning air masses exhibited lower $\kappa_{\mathrm{CCN}}$ and $\kappa_{\mathrm{org}}$ values during night and stronger diel variations. In the afternoon, $\kappa_{\text {org }}$ and $\mathrm{O}: \mathrm{C}$ reached high values of 0.14 and 0.86 , respectively, as observed for background aerosols.

For urban pollution air masses, aerosol number and volume concentrations showed similar trends for both seasons. The increases in number and volume concentration from early morning to noon were similar, about $1000 \mathrm{~cm}^{-3}$ and $0.5 \mu \mathrm{m}^{3} \mathrm{~cm}^{-3}$, respectively, for both wet and dry seasons. The percentage increases were less pronounced in the dry season due to the higher background values. In contrast to urban pollution, local biomass burning showed higher aerosol number and volume concentrations at night and decreased during the morning. Local biomass burning activities typically peaked during evening hours, consistent with frequent classification of the nighttime aerosol as local biomass burning (Fig. 7i; Vestin et al., 2007). Despite the wet removal of particles by fog, the strong emission from local biomass burning, largely confined within the shallow nocturnal boundary layer, led to higher surface aerosol concentrations than those in the residue layer aloft, which likely represented the regional background. As the boundary layer deepened in the morning, the mixing with aerosol from the residual layer led to decreases in both aerosol number and volume concentration observed at the surface (Fig. 7e and f).

\subsection{Hygroscopicity of PMF factors and the variation of organic hygroscopicity with oxidation level}

The hygroscopicities associated with the AMS PMF factors were estimated through multivariable linear regression using different subsets of the data as well as the entire dataset for each of the two IOPs (IOP1 in Fig. 9 and IOP2 in Fig. 10). The different subsets included measurements during day, night, certain sampling periods, and ranges in particle hygroscopicity dispersion. Comparison of the hygroscopicities derived from the different subsets of data allowed us to examine the robustness of this approach. Uncertainty in the derived $\kappa$ for individual factors was determined by the number of points available to fit in the time series, with greater data coverage and therefore lower uncertainty during the dry season. For the wet season (IOP1), the hygroscopicities associated with PMF factors derived using different subsets of the data are largely in agreement with those derived from the entire dataset. There are notable differences between the hygroscopicities of MO-OOA and Fac91 factors derived using data under background conditions only and those derived using the entire dataset. Such difference could be partially due to the limited data under the background conditions during 
(a) $\kappa_{\mathrm{CCN}}$

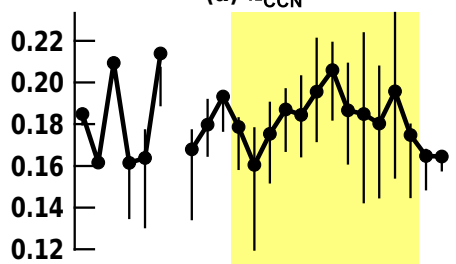

(d) $\kappa_{\text {org }}$

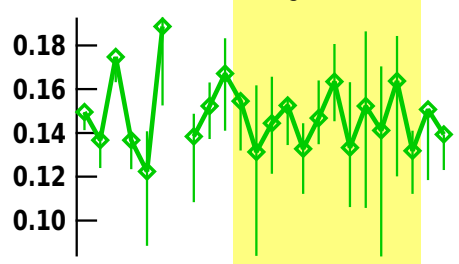

(g) PBL height (km)

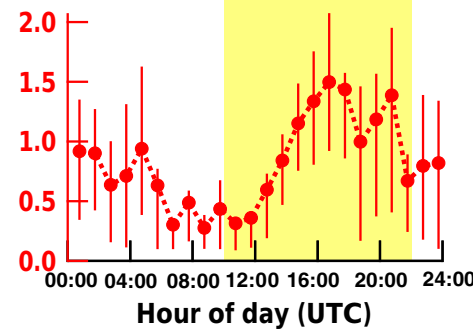

(b) $\sigma_{k} / \kappa_{\mathrm{CCN}}$

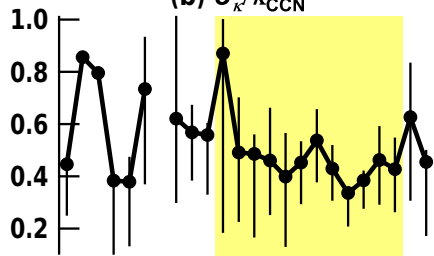

(e) $N_{\mathrm{CN}}\left(\mathrm{cm}^{-3}\right)$

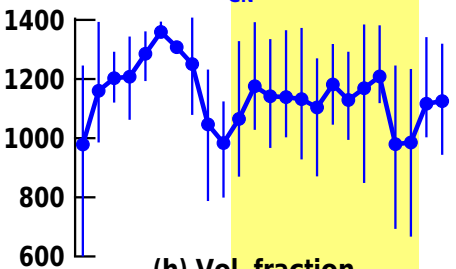

(h) Vol. fraction

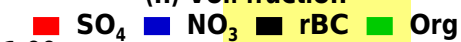

100

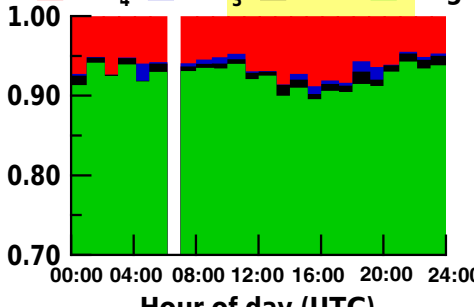

Hour of day (UTC)

Dry season - background conditions (c) $f_{44} ; 0: C$

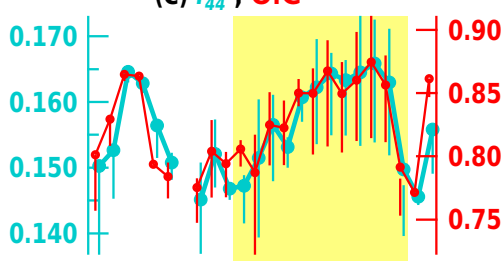

(f) Volume $\left(\mu \mathrm{m}^{3} \mathrm{~cm}^{-3}\right)$

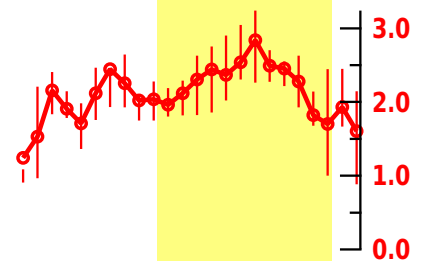

(i) No. of data points

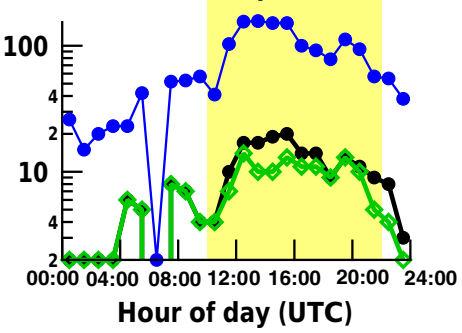

Figure 5. Diel variations of aerosol properties and meteorological parameters under background conditions during the dry season (analogous to Fig. 3).

IOP1 (Fig. 3). For the dry season (IOP2), the hygroscopicities of PMF factors derived using measurements under background conditions or data with hygroscopicity dispersion less than 0.4 are quite different from those derived using other data subsets and the entire dry season dataset. The agreement among the PMF factor hygroscopicities derived using different sub-datasets during the wet season and the disagreements for the dry season are attributed to the applicability of the underlying assumption that the bulk volume fractions of PMF factors (i.e., derived from MS mode data) represented those at the sizes of $\mathrm{CCN}$ measurements. For the wet season, the average $f_{44}$ was largely independent of particle size from 130 to $400 \mathrm{~nm}$ (Fig. S10), which is the size range that dominated the bulk aerosol mass concentration measured by AMS. This is consistent with the assumption that the bulk volume fractions of the PMF factors represent those at the two CCN sizes $\left(142\right.$ and $171 \mathrm{~nm}$ ). For the dry season, the $f_{44}$ averaged over local biomass burning air masses and the entire IOP2 exhibited an increase with particle diameter from 100 to $300 \mathrm{~nm}$ (Fig. S10). For periods with hygroscopicity dispersion less than 0.4 or under background conditions, the average size distribution of $f_{44}$ was noisier due to fewer data points. Nevertheless, the size distribution shows $f_{44}$ was largely independent of the particle size under these conditions, consistent with the assumption described above. In the following discussion, we focus on the PMF factor hygroscopicities de- rived using all data during the wet season and under background conditions in the dry season.

The MO-OOA factors for the two IOPs exhibit very similar $\mathrm{O}: \mathrm{C}$ and $\kappa$ values. The $\mathrm{O}: \mathrm{C}$ values were 1.19 and 1.24 , and $\kappa$ values were 0.20 and 0.21 , for IOP1 and 2, respectively (Table 1). The $\mathrm{O}: \mathrm{C}$ and $\kappa$ values are consistent with those of some typical SOA compounds, such as malonic acid, which has an $\mathrm{O}: \mathrm{C}$ value of 1.33 and a $\kappa$ value of 0.23 (Kumar et al., 2003), and succinic acid, which has an $\mathrm{O}: \mathrm{C}$ value of 1 and a $\kappa$ value of 0.23 (Hori et al., 2003). For the LO-OOA and IEPOX-SOA factors, the hygroscopicities vary between the two IOPs. The $\kappa$ values of IEPOX-SOA were 0.18 and 0.08 during IOP1 and IOP2, respectively, and the $\kappa$ values of the LO-OOA factor varied from 0.12 to 0.20 between IOP1 and IOP2. The difference in $\kappa$ may be partially due to the change of $\mathrm{O}: \mathrm{C}$ values of the factors derived for the two IOPs. The difference in SOA precursors and therefore composition in LO-OOA (Ng et al., 2010) may also contribute to the difference in its $\kappa$ values between the two IOPs. The variation of IEPOX-SOA $\kappa$ between the two IOPs could be a result of the different RH conditions, which may strongly influence the composition of IEPOX-SOA (Riva et al., 2016).

During the wet season, a factor with high contribution from $m / z=91$ was identified. The Fac91 factor correlates with several tracers for anthropogenic emissions, including $\mathrm{NO}_{x}$, benzene, toluene, trimethylbenzene (TMB), and 


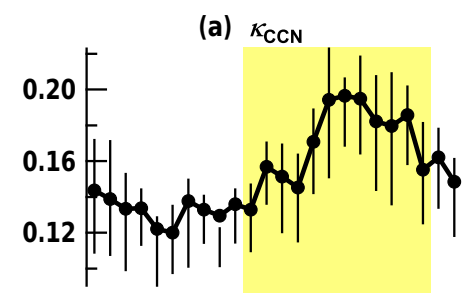

(d) $\kappa_{\text {org }}$

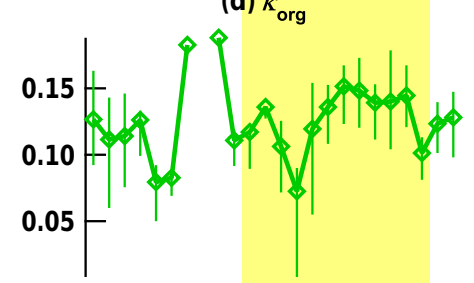

(g) PBL height (km)

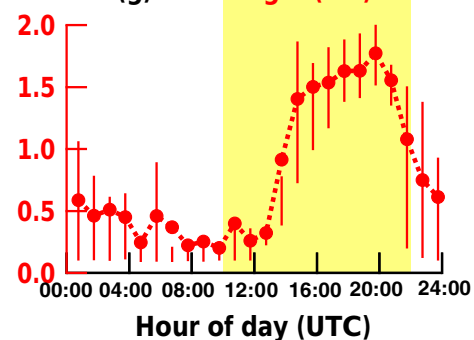

(b) $\sigma_{\kappa} / \kappa_{\mathrm{CCN}}$

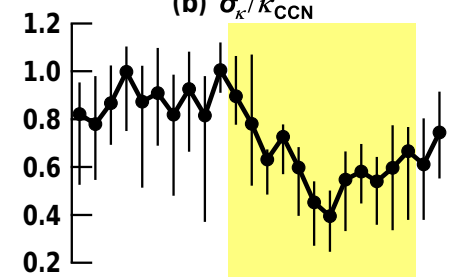

(e) $N_{\mathrm{CN}}\left(\mathrm{cm}^{-3}\right)$

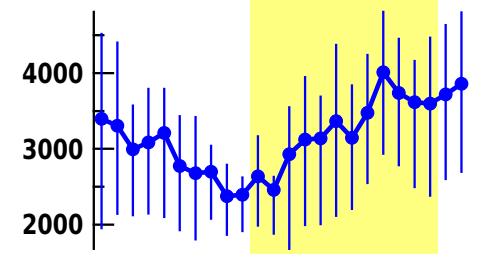

(h) Vol, fraction

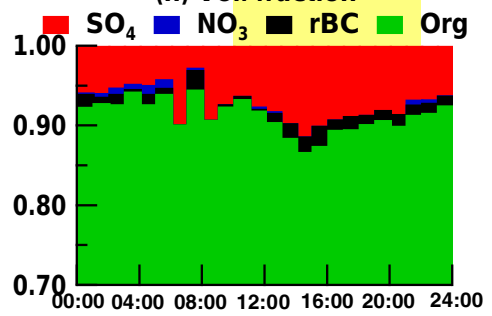

Hour of day (UTC)

Dry season - polluted conditions

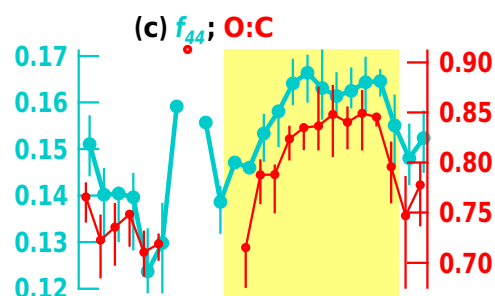

(f) Volume $\left(\mu \mathrm{m}^{3} \mathrm{~cm}^{-3}\right)$

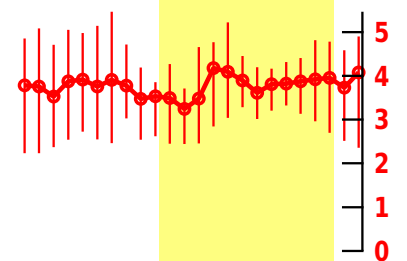

(i) No. of data points

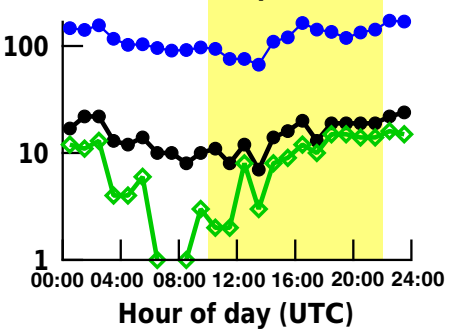

Figure 6. Diel variations of aerosol properties and meteorological parameters for urban pollution air masses during the dry season (analogous to Fig. 3).

xylenes, but not high $\mathrm{NO}_{x}$ isoprene products (e.g., methylglyceric acid; de Sá et al., 2017b). This factor likely represents SOA formed from aromatics emitted from urban areas, possibly combined with a mixture of freshly oxidized biogenic compounds within the urban-influenced air (de Sá et al., 2017b). The Fac91 factor has a hygroscopicity value of 0.10 and a much lower $\mathrm{O}: \mathrm{C}$ ratio of 0.328 compared to those of MO-OOA and LO-OOA.

The less-oxidized organic factors identified by the PMF analysis were HOA for both IOPs, BBOA for IOP1, and fresh and aged BBOA for IOP2. These factors represent primary OA, except that the aged BBOA of IOP2 likely included contributions from oxidized POA or SOA. The hygroscopicity of the HOA factors was fixed as zero in the multivariate regressions. All BBOA factors have a distinctive $m / z=60$ peak and correlate with biomass burning traces including levoglucosan and vanillin (de Sá et al., 2017b). The retrieved hygroscopicity values for the BBOA factors are substantially lower than those of SOA factors, especially for the fresh-BBOA factor during IOP2. The extremely low hygroscopicity suggests that the fresh BBOA, likely produced by local fires, behaves very similar to HOA in terms of $\mathrm{CCN}$ activation despite a substantially higher $\mathrm{O}: \mathrm{C}$.

Figures 11 and 12 show that for SOA factors, including IEPOX-SOA, LO-OOA, MO-OOA for both IOPs, and Fac91 for IOP1, the $\kappa$ value increases with increasing $\mathrm{O}: \mathrm{C}$, and the variation of $\kappa$ with $\mathrm{O}: \mathrm{C}$ agrees with the linear relationship derived from laboratory studies of SOA CCN activities (Lambe et al., 2011). The low hygroscopicities of the HOA and the BBOA factors, which are below the linear relationship for SOAs, are also consistent with laboratory results of POA and oxidized POA (Lambe et al., 2011). Cerully et al. (2015) derived $\kappa$ of LO-OOA, MO-OOA, and IEPOXSOA factors from data collected in the southeastern US during the Southern Oxidant and Aerosol Study (SOAS). A different name, isoprene-OA, was used for the IEPOX-SOA factor in Cerully et al. (2015), as, while this factor is mainly attributed to SOA formed from IEPOX uptake, it might not be entirely due to IEPOX (Schwantes et al., 2015; Xu et al., $2015 \mathrm{a}, \mathrm{b})$. The $\mathrm{O}: \mathrm{C}$ values calculated using the ImprovedAmbient method (Canagaratna et al., 2015) are 0.59, 0.61, and 0.92 for the IEPOX-SOA, LO-OOA, and MO-OOA factors reported in Cerully et al. (2015), respectively (personal communication, L. Xu and N.L. Ng). For the LO-OOA and MO-OOA factors reported in Cerully et al. (2015), the $\kappa$ and $\mathrm{O}: \mathrm{C}$ values are largely consistent with the linear relationship between $\kappa$ and O:C derived from Lambe et al. (2011). Cerully et al. (2015) also reported a IEPOX-SOA (i.e., called isoprene-OA in their study) factor $\kappa$ of 0.2 , similar to the 0.18 derived for IOP1. The $\mathrm{O}: \mathrm{C}$ value of the IEPOX-SOA factor during the SOAS study was 0.59 , which is somewhat lower than those derived from both IOPs of GoAma- 


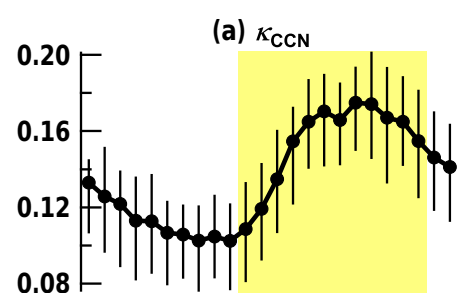

(d) $\kappa_{\text {org }}$

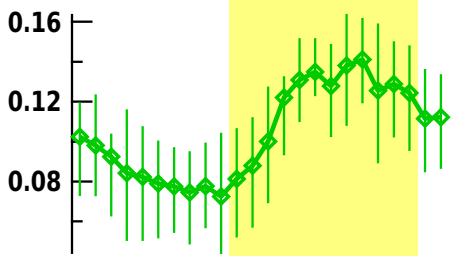

(g) PBL Height (km)

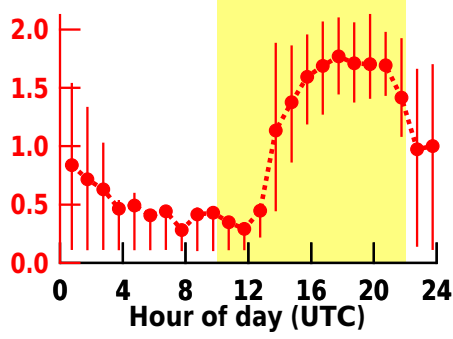

(b) $\sigma_{\kappa} / \kappa_{\mathrm{CCN}}$

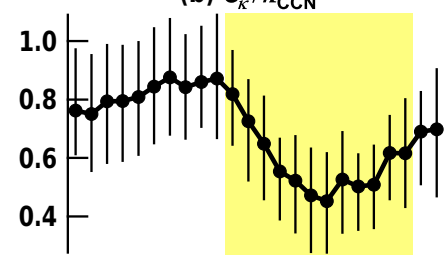

(e) $N_{\mathrm{CN}}\left(\mathrm{cm}^{-3}\right)$

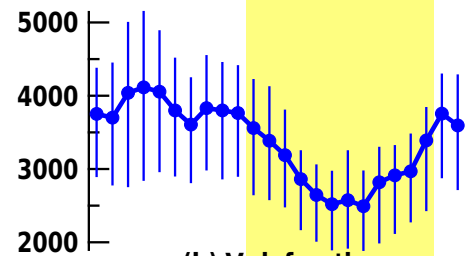

(h) Vol. fraction

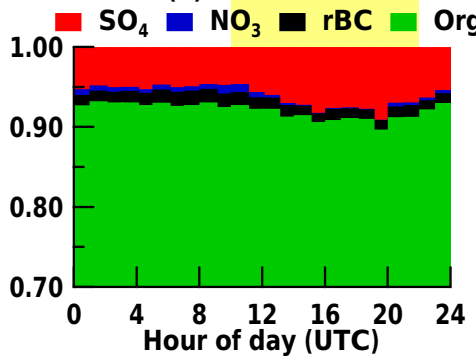

(c) $f_{44} ; 0: C$

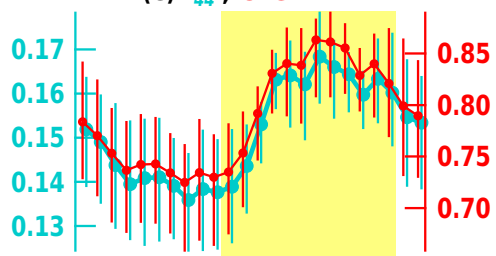

(f) Volume $\left(\mu \mathrm{m}^{3} \mathrm{~cm}^{-3}\right)$

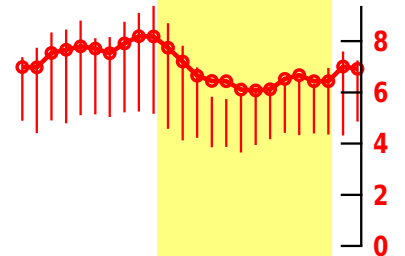

(i) No. of data points

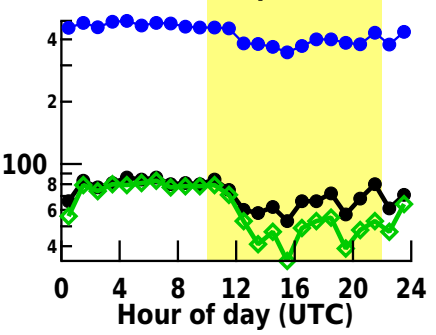

Dry season - biomass burning conditions

Figure 7. Diel variations of aerosol properties and meteorological parameters for local biomass burning air masses during the dry season (analogous to Fig. 3).
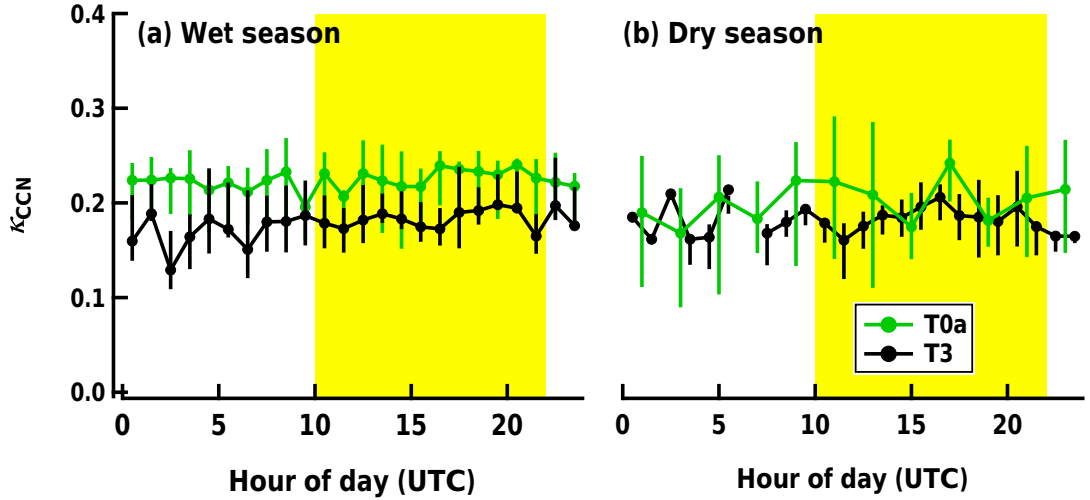

Figure 8. Comparison $\kappa_{\mathrm{CCN}}$ values derived from measurements at the T0a (ATTO) site (Pöhlker et al., 2016) and at the T3 site under background conditions (this study) during the (a) wet season (April and May 2014) and (b) dry season. The size-resolved CCN data at T0a was collected by stepping the particle size at given CCNC supersaturations (Rose et al., 2008). Data displayed for T0a are averaged over critical particle diameters ranging from 44 to $175 \mathrm{~nm}$, while the T3 data are averaged from measurements at 112,142 , and $171 \mathrm{~nm}$.

zon2014/5. While the IEPOX-SOA factors identified using different datasets share many similar features, they are not identical and can consist of different groups of compounds. Such differences may be due to varying degrees of oxidation in different environments between the two field campaigns.

For comparison with earlier field studies, the values of $\kappa_{\text {org }}$ and $\mathrm{O}: \mathrm{C}$ were averaged according to the hours of the day over particle diameters of 142 and $171 \mathrm{~nm}$ for data under polluted conditions during IOP1 and all data during IOP2 (Figs. 11 and 12). For the $1 \mathrm{~h}$ diel averages, the slope of $\kappa_{\text {org }}$ vs. O:C, derived through a bivariate least squares fit (i.e., orthogonal distance regression), is steeper than that derived from laboratory studies of SOA hygroscopicity, especially during IOP2. This steep slope during IOP2 is consistent with the results from earlier field studies (Mei et al., 2013b), although there is a clear offset between the 


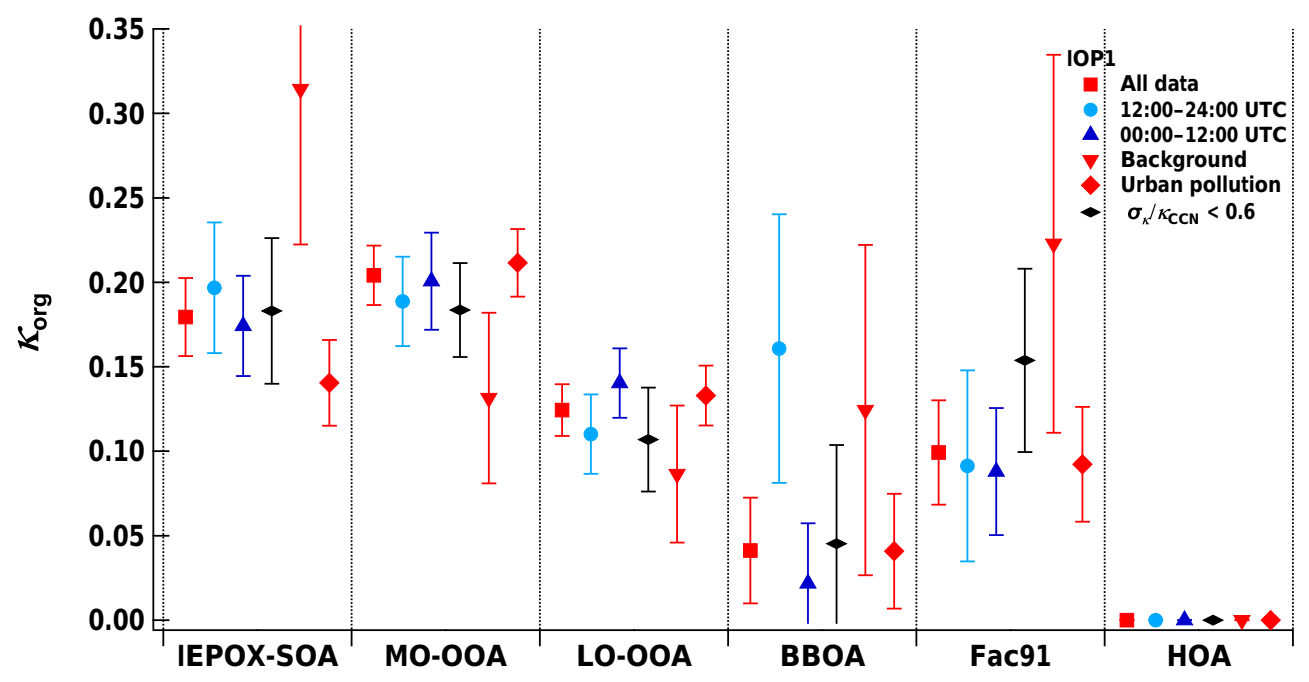

Figure 9. Hygroscopicity of AMS PMF factors for IOP1 (i.e., wet season) retrieved by multilinear regressions using all data (red square), data from UTC 12:00-24:00 (cyan circle), data from UTC 00:00-12:00 (blue triangle), data under background conditions (red triangle), data under polluted conditions (red diamond), and data with hygroscopicity dispersion $\sigma_{\kappa_{\mathrm{CCN}}} / \bar{\kappa}_{\mathrm{CCN}}$ less than 0.6 (black diamond).

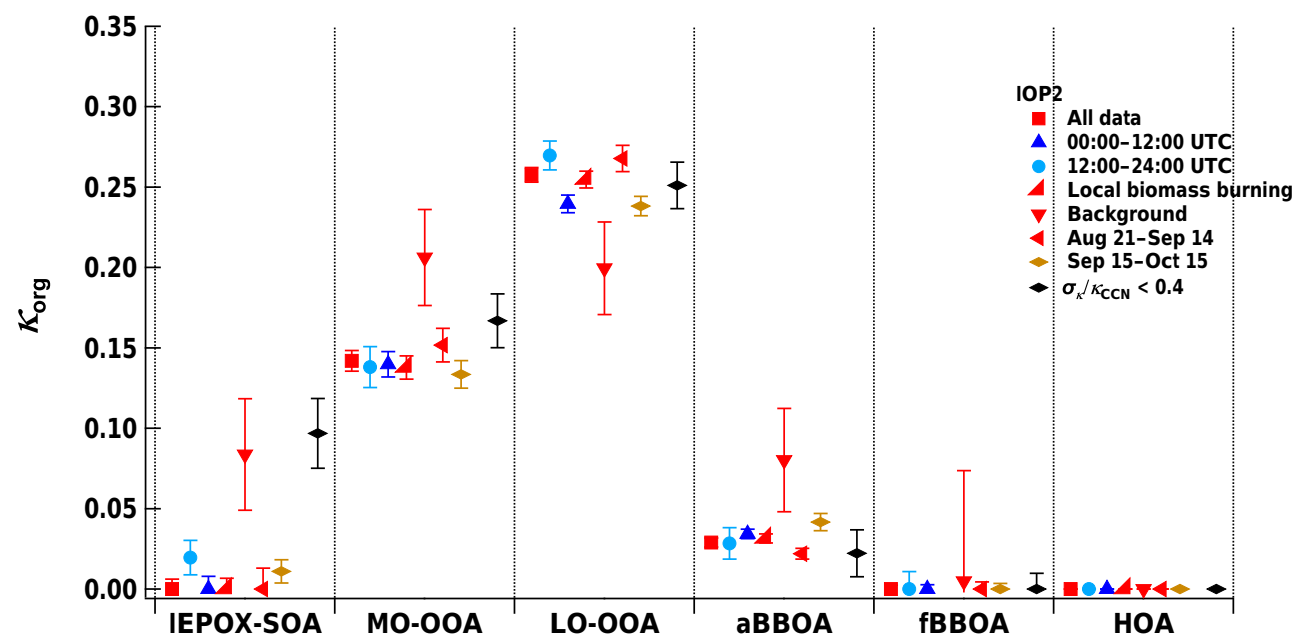

Figure 10. Hygroscopicity of PMF factors for IOP2 (i.e., dry season) retrieved by multilinear regressions using all data (red square), data from UTC 12:00-24:00 (cyan circle), data from UTC 00:00-12:00 (blue triangle), data with strong influence from local biomass burning (red right triangle), data under background conditions (red upside-down triangle), data from 21 August to 14 September 2014 only (red left-pointing triangle), data from 15 September to 15 October only (brown diamond), and data with a dispersion $\left(\sigma_{\kappa_{\mathrm{CCN}}} / \bar{\kappa}_{\mathrm{CCN}}\right)<0.4($ black diamond).

two relationships. The O : C ratios from Mei et al. (2013b) and Lambe et al. (2011) were scaled by a factor of 1.27 to account for changes in the method of calculating the $\mathrm{O}: \mathrm{C}$ ratio (Improved-Ambient, Canagaratna et al., 2015), while all $\mathrm{O}: \mathrm{C}$ values from this work were calculated using the Improved-Ambient method. This offset between the field studies may be partially due to the different precursors of the SOA for the campaigns, with a higher anthropogenic volatile organic compound fraction expected for CalNex and CARES, which took place near Los Angeles and Sacramento, respectively. In addition, biomass burning represented a much smaller fraction of the organics during CalNex and CARES (Mei et al., 2013a, b). The factors associated with secondary processes (e.g., MO-OOA, LO-OOA, and IEPOX-SOA), which have higher $\mathrm{O}: \mathrm{C}$ values, exhibited higher volume fractions during the day, whereas the factors associated with primary emissions (e.g., HOA and BBOA), which have lower $\mathrm{O}: \mathrm{C}$, had higher volume fractions during the night (de Sá et al., 2017b). As a result, the diel trend of overall $\mathrm{O}: \mathrm{C}$ was to a large degree driven by the variations in volume fractions of the POA and SOA factors with very different $\mathrm{O}: \mathrm{C}$ values. This is in contrast to laboratory studies, in 


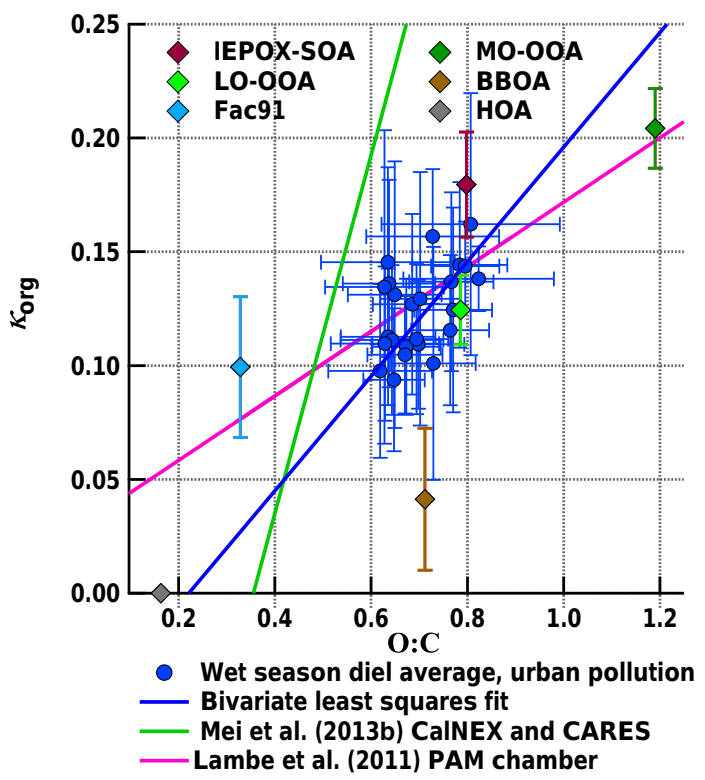

Figure 11. The variation of PMF factor hygroscopicity, $1 \mathrm{~h}$ diel average of organic hygroscopicity, and $\mathrm{O}: \mathrm{C}$ ratio at 142 and $171 \mathrm{~nm}$ for urban pollution air masses. Also shown are the relationships between $\kappa_{\text {org }}$ and $\mathrm{O}: \mathrm{C}$ reported by earlier field and laboratory studies.

which the increase in $\mathrm{O}: \mathrm{C}$ was mainly driven by oxidation. As POA exhibits hygroscopicity values well below the linear fit between SOA hygroscopicity and $\mathrm{O}: \mathrm{C}$, mixtures with different POA and SOA fractions lead to a steeper slope for the increase in $\kappa_{\text {org }}$ with $\mathrm{O}: \mathrm{C}$, as shown by the results from this and previous field studies (Mei et al., 2013b).

\section{Conclusions}

Size-resolved CCN spectra at five particle diameters ranging from 75 to $171 \mathrm{~nm}$ were characterized downwind of Manaus, Brazil, in central Amazonia for a period of 1 year from 12 March 2014 to 3 March 2015 during GoAmazon2014/5. For each season, the air masses arriving at the site were classified into different types, including background, urban pollution, and local biomass burning. During the wet season, the background air mass represented near-natural conditions, at times with impact from anthropogenic emissions, while, in the dry season, the background was dominated by regional and long-distance biomass burning aerosol particles. Polluted air masses represented those with strong influence from urban emissions, which were mostly from Manaus. The local-biomass-burning type describes those strongly influenced by local (i.e., fresh) biomass mass burning activities that dominate the impact from urban pollution, if any.

Particle hygroscopicity, mixing state, and organic hygroscopicity were derived from size-resolved $\mathrm{CCN}$ activation fraction and concurrent aerosol composition measurements. The monthly mean $\kappa_{\mathrm{CCN}}$ exhibits the lowest values during

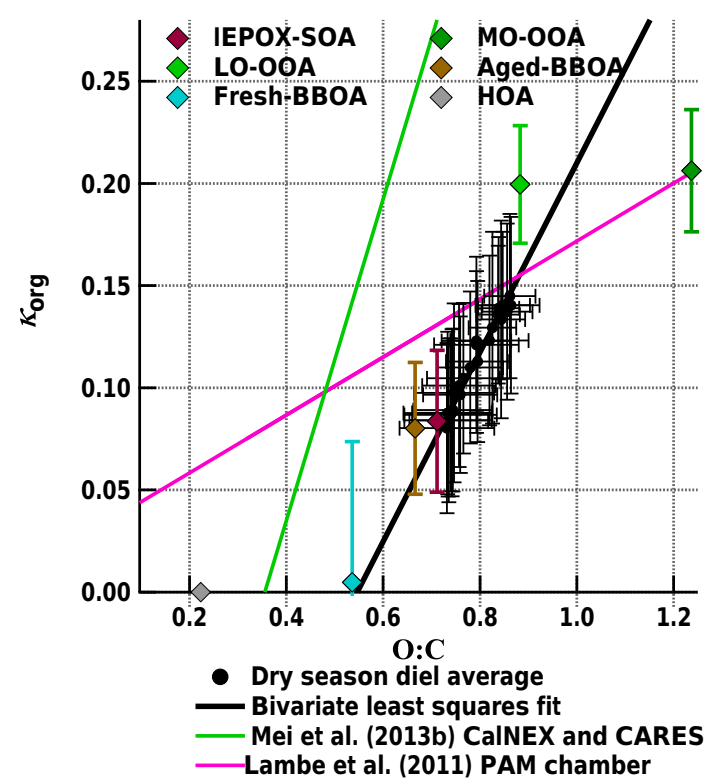

Figure 12. The variation of PMF factor hygroscopicity, $1 \mathrm{~h}$ diel average of organic hygroscopicity, and O : C ratio at 142 and $171 \mathrm{~nm}$ for local biomass burning air masses. Also shown are the relationships between $\kappa_{\text {org }}$ and $\mathrm{O}: \mathrm{C}$ reported by earlier field and laboratory studies.

the dry season, largely due to lower $\kappa_{\text {org }}$ when aerosol was often strongly influenced by local biomass burning. The $\kappa_{\mathrm{CCN}}$ increased with particle size during all seasons, consistent with decreasing organic volume fraction with increasing particle size. Under background conditions, the value of $\kappa_{\mathrm{CCN}}$ and its size dependence were largely consistent among different seasons, despite the very different aerosol sources. During the dry season, aerosols classified as urban pollution and local biomass burning exhibited lower $\kappa_{\text {org }}$ values compared to background aerosols, contributing to the lower values of overall $\kappa_{\mathrm{CCN}}$.

Under background conditions during both wet and dry seasons, the largely constant diel trends of $\kappa_{\mathrm{CCN}}$ and $\kappa_{\text {org }}$ suggest little variation in particle composition throughout the day. The constant $\kappa_{\text {org }}$ of $\sim 0.15$ is consistent with the lack of a diel trend in $f_{44}$ and $\mathrm{O}: \mathrm{C}$. The high values of $f_{44}$ and $\mathrm{O}: \mathrm{C}$ indicate that the aerosols under background conditions are dominated by the aged regional aerosol particles consisting of highly oxygenated organic compounds. When the air mass is influenced by urban pollution or local biomass burning, $\kappa_{\mathrm{CCN}}, \kappa_{\mathrm{org}}, f_{44}$, and $\mathrm{O}: \mathrm{C}$ exhibit clear diel variations. The value of $\kappa_{\mathrm{CCN}}(0.1-0.2)$ is lower during the night and increases from the early morning hours, peaking around noon (LT, UTC $-4 \mathrm{~h}$ ). This diel trend of $\kappa_{\mathrm{CCN}}$ is largely driven by the variation in $\kappa_{\text {org }}(0.08-0.15)$, consistent with the variation of $\mathrm{O}: \mathrm{C}$. The dispersion of $\kappa_{\mathrm{CCN}}$ is anticorrelated with $\kappa_{\mathrm{CCN}}$, exhibiting higher values during night and a minimum value around noon, indicating an increased heterogeneity in particle chemical composition during nighttime. These diel 
variations for air masses strongly influenced by urban pollution and local biomass burning indicate that, during the night, freshly emitted particles, dominated by POA and with low hygroscopicity, are mixed with more aged particles within a shallow nocturnal boundary layer. In the absence of photochemical oxidation and aging, this external mixture leads to higher dispersion of particle hygroscopicity as well as overall lower $\mathrm{O}: \mathrm{C}$ and $\kappa_{\text {org }}$. The increases in $\mathrm{O}: \mathrm{C}$ and $\kappa_{\text {org }}$ during daytime are driven by the formation and aging of SOA and dilution of POA emissions into a deeper boundary layer, while the development of the boundary layer, which leads to mixing with aged particles from the residual layer, likely also contributes to the increases.

The hygroscopicities associated with individual PMF organic factors were derived through multivariable linear regression. For the SOA factors, $\kappa$ increases within increasing $\mathrm{O}: \mathrm{C}$, and the variation of $\kappa$ with $\mathrm{O}: \mathrm{C}$ agrees well with the linear relationship derived from laboratory studies of SOA hygroscopicity (Lambe et al., 2011). The low hygroscopicity of HOA and the BBOA factors, which are below the linear relationship, are also consistent with laboratory results of POA and oxidized POA (Lambe et al., 2011). In contrast, the slope of $\kappa_{\text {org }}$ (i.e., overall organic hygroscopicity) vs. O:C is much steeper when compared to that derived from laboratory studies of SOA hygroscopicity, especially for IOP2. Such difference is due to the increase in $\mathrm{O}: \mathrm{C}$ being driven primarily by oxidation in laboratory SOA studies, while the variation in $\mathrm{O}: \mathrm{C}$ of ambient organics is to a large degree due to the variations in volume fractions of POA and SOA factors, which have very different $\mathrm{O}: \mathrm{C}$ values. As POA factors show hygroscopicity values well below the linear fit between SOA hygroscopicity and $\mathrm{O}: \mathrm{C}$, mixtures with different POA and SOA fractions lead to a steeper slope for the increase in $\kappa_{\text {org }}$ with $\mathrm{O}: \mathrm{C}$, as shown by the results from this and earlier field studies (Mei et al., 2013b).

Data availability. The datasets used in this publication are available at the ARM Climate Research Facility database for the GoAmazon2014/5 experiment (https://www.arm.gov/research/ campaigns/amf2014goamazon).

\section{The Supplement related to this article is available online at https://doi.org/10.5194/acp-17-11779-2017- supplement.}

Competing interests. The authors declare that they have no conflict of interest.

Special issue statement. This article is part of the special issue "Observations and Modeling of the Green Ocean Amazon (GoAmazon2014/5) (ACP/AMT/GI/GMD inter-journal SI)”. It is not associated with a conference.
Acknowledgements. We acknowledge the support from the Central Office of the Large-Scale Biosphere-Atmosphere Experiment in Amazonia (LBA), the National Institute of Amazonian Research (INPA), Amazonas State University (UEA), and the Max Planck Society (MPG). The Office of Biological and Environmental Research of the Office of Science of the United States Department of Energy is acknowledged for funding, specifically the Atmospheric Radiation Measurement (ARM) Climate Research Facility and the Atmospheric System Research (ASR) Program. The work was conducted under scientific license 001030/2012-4 of the Brazilian National Council for Scientific and Technological Development (CNPq). Nga Lee $\mathrm{Ng}$ acknowledges support from NSF grant 1242258 and US Environmental Protection Agency (EPA) STAR grant RD-83540301. This publication's contents are solely the responsibility of the grantee and do not necessarily represent the official views of the US EPA. Further, the US EPA does not endorse the purchase of any commercial products or services mentioned in the publication. Paulo Artaxo and Henrique M. J. Barbosa acknowledge the support from FAPESP under research grants 13/50510-5 and 13/05014-0 and from the Royal Society under research grant NA 140450.

Edited by: Maria Assuncao Silva Dias

Reviewed by: two anonymous referees

\section{References}

Albrecht, B. A.: Aerosols, cloud microphysics, and fractional cloudiness, Science, 245, 1227-1230, 1989.

Andreae, M. O. and Gelencsér, A.: Black carbon or brown carbon? The nature of light-absorbing carbonaceous aerosols, Atmos. Chem. Phys., 6, 3131-3148, https://doi.org/10.5194/acp-63131-2006, 2006.

Andreae, M. O. and Rosenfeld, D.: Aerosol-cloud-precipitation interactions, Part 1, The nature and sources of cloud-active aerosols, Earth-Sci. Rev., 89, 13-41, 2008.

Andreae, M. O., Acevedo, O. C., Araùjo, A., Artaxo, P., Barbosa, C. G. G., Barbosa, H. M. J., Brito, J., Carbone, S., Chi, X., Cintra, B. B. L., Silva, N. F. d., Dias, N. L., DiasJúnior, C. Q., Ditas, F., Ditz, R., Godoi, A. F. L., Godoi, R. H. M., Heimann, M., Hoffmann, T., Kesselmeier, J., Könemann, T., Krüger, M. L., Lavric, J. V., Manzi, A. O., Moran-Zuloaga, D., Nölscher, A. C., Nogueira, D. S., Piedade, M. T. F., Pöhlker, C., Pöschl, U., Rizzo, L. V., Ro, C.-U., Ruckteschler, N., Sá, L. D. A., Sá, M. D. O., Sales, C. B., Santos, R. M. N. D., Saturno, J., Schöngart, J., Sörgel, M., Souza, C. M. d., Souza, R. A. F. d., H. Su, N., Targhetta, Tóta, J., Trebs, I., Trumbore, S., Eijck, A. v., Walter, D., Wang, Z., Weber, B., Williams, J., Winderlich, J., Wittmann, F., Wolff, S., and Yáñez-Serrano, A. M.: The Amazon Tall Tower Observatory (ATTO): overview of pilot measurements on ecosystem ecology, meteorology, trace gases, and aerosols, Atmos. Chem. Phys., 15, 10723-10776, https://doi.org/10.5194/acp-15-107232015, 2015.

Asa-Awuku, A., Engelhart, G. J., Lee, B. H., Pandis, S. N., and Nenes, A.: Relating CCN activity, volatility, and droplet growth kinetics of beta-caryophyllene secondary organic aerosol, At- 
mos. Chem. Phys., 9, 795-812, https://doi.org/10.5194/acp-9795-2009, 2009.

Bateman, A. P., Gong, Z., Harder, T. H., de Sá, S. S., Wang, B., Castillo, P., China, S., Liu, Y., O’Brien, R. E., Palm, B. B., Shiu, H.-W., Cirino, G. G., Thalman, R., Adachi, K., Alexander, M. L., Artaxo, P., Bertram, A. K., Buseck, P. R., Gilles, M. K., Jimenez, J. L., Laskin, A., Manzi, A. O., Sedlacek, A., Souza, R. A. F., Wang, J., Zaveri, R., and Martin, S. T.: Anthropogenic influences on the physical state of submicron particulate matter over a tropical forest, Atmos. Chem. Phys., 17, 1759-1773, https://doi.org/10.5194/acp-17-1759-2017, 2017.

Batistella, M., Artaxo, P., Nobre, C., Bustamante, M., and Luizão, F.: Results from LBA and a vision for future Amazonian research, in: Amazonia and Global Change, American Geophysical Union, Washington, DC, https://doi.org/10.1029/2008GM000738, 2009.

Bond, T. C. and Bergstrom, R. W.: Light absorption by carbonaceous particles: an investigative review, Aerosol Sci. Tech., 40, 27-67, 2006.

Bougiatioti, A., Nenes, A., Fountoukis, C., Kalivitis, N., Pandis, S. N., and Mihalopoulos, N.: Size-resolved CCN distributions and activation kinetics of aged continental and marine aerosol, Atmos. Chem. Phys., 11, 8791-8808, https://doi.org/10.5194/acp-11-8791-2011, 2011.

Canagaratna, M. R., Jimenez, J. L., Kroll, J. H., Chen, Q., Kessler, S. H., Massoli, P., Hildebrandt Ruiz, L., Fortner, E., Williams, L. R., Wilson, K. R., Surratt, J. D., Donahue, N. M., Jayne, J. T., and Worsnop, D. R.: Elemental ratio measurements of organic compounds using aerosol mass spectrometry: characterization, improved calibration, and implications, Atmos. Chem. Phys., 15, 253-272, https://doi.org/10.5194/acp-15-2532015, 2015.

Cappa, C. D., Bates, T. S., Quinn, P. K., and Lack, D. A.: Source characterization from ambient measurements of aerosol optical properties, Geophys. Res. Lett., 36, L14813, https://doi.org/10.1029/2009GL038979, 2009.

Cappa, C. D., Che, D. L., Kessler, S. H., Kroll, J. H., and Wilson, K. R.: Variations in organic aerosol optical and hygroscopic properties upon heterogeneous $\mathrm{OH}$ oxidation, J. Geophys. Res.Atmos., 116, D15204, https://doi.org/10.1029/2011JD015918., 2011

Carslaw, K. S., Lee, L. A., Reddington, C. L., Pringle, K. J., Rap, A., Forster, P. M., Mann, G. W., Spracklen, D. V., Woodhouse, M. T., Regayre, L. A., and Pierce, J. R.: Large contribution of natural aerosols to uncertainty in indirect forcing, Nature, 503, 67-71, 2013.

Cerully, K. M., Raatikainen, T., Lance, S., Tkacik, D., Tiitta, P., Petäjä, T., Ehn, M., Kulmala, M., Worsnop, D. R., Laaksonen, A., Smith, J. N., and Nenes, A.: Aerosol hygroscopicity and CCN activation kinetics in a boreal forest environment during the 2007 EUCAARI campaign, Atmos. Chem. Phys., 11, 12369-12386, https://doi.org/10.5194/acp-11-12369-2011, 2011.

Cerully, K. M., Bougiatioti, A., Hite, J. R., Guo, H., Xu, L., $\mathrm{Ng}, \mathrm{N}$. L., Weber, R., and Nenes, A.: On the link between hygroscopicity, volatility, and oxidation state of ambient and water-soluble aerosols in the southeastern United States, Atmos. Chem. Phys., 15, 8679-8694, https://doi.org/10.5194/acp15-8679-2015, 2015.
Chang, R. Y. W., Slowik, J. G., Shantz, N. C., Vlasenko, A., Liggio, J., Sjostedt, S. J., Leaitch, W. R., and Abbatt, J. P. D.: The hygroscopicity parameter $(\kappa)$ of ambient organic aerosol at a field site subject to biogenic and anthropogenic influences: relationship to degree of aerosol oxidation, Atmos. Chem. Phys., 10, 5047-5064, https://doi.org/10.5194/acp-10-5047-2010, 2010.

Chen, Q., Farmer, D. K., Schneider, J., Zorn, S. R., Heald, C. L., Karl, T. G., Guenther, A., Allan, J. D., Robinson, N., Coe, H., Kimmel, J. R., Pauliquevis, T., Borrmann, S., Pöschl, U., Andreae, M. O., Artaxo, P., Jimenez, J. L., and Martin, S. T.: Mass spectral characterization of submicron biogenic organic particles in the Amazon Basin, Geophys. Res. Lett., 36, L20806, https://doi.org/10.1029/2009GL039880, 2009.

Chen, Q., Farmer, D. K., Rizzo, L. V., Pauliquevis, T., Kuwata, M., Karl, T. G., Guenther, A., Allan, J. D., Coe, H., Andreae, M. O., Pöschl, U., Jimenez, J. L., Artaxo, P., and Martin, S. T.: Submicron particle mass concentrations and sources in the Amazonian wet season (AMAZE-08), Atmos. Chem. Phys., 15, 3687-3701, https://doi.org/10.5194/acp-15-3687-2015, 2015.

Davidson, E. A., de Araujo, A. C., Artaxo, P., Balch, J. K., Brown, I. F., Bustamante, C., M. M., Coe, M. T., DeFries, R. S., Keller, M., Longo, M., Munger, J. W., Schroeder, W., SoaresFilho, B. S., Souza, C. M., and Wofsy, S. C.: The Amazon basin in transition, Nature, 481, 321-328, 2012.

de Sá, S. S., Palm, B. B., Campuzano-Jost, P., Day, D. A., Newburn, M. K., Hu, W., Isaacman-VanWertz, G., Yee, L. D., Thalman, R., Brito, J., Carbone, S., Artaxo, P., Goldstein, A. H., Manzi, A. O., Souza, R. A. F., Mei, F., Shilling, J. E., Springston, S. R., Wang, J., Surratt, J. D., Alexander, M. L., Jimenez, J. L., and Martin, S. T.: Influence of urban pollution on the production of organic particulate matter from isoprene epoxydiols in central Amazonia, Atmos. Chem. Phys., 17, 6611-6629, https://doi.org/10.5194/acp-17-6611-2017, 2017a.

de Sá, S. S., Palm, B. B., Campuzano-Jost, P., Day, D. A., Hu, W., Isaacman-VanWertz, G., Yee, L. D., Brito, J., Carbone, S., Liu, Y., Thalman, R., Funk, A., Schumacher, C., Artaxo, P., Goldstein, A. H., Souza, R. A. F., Wang, J., McKinney, K., Barbosa, H., Alexander, M. L., Jimenez, J. L., and Martin, S. T.: Anthropogenic emissions affect the amount and composition of submicron particulate matter in central Amazonia, to be submitted to Atmos. Chem. Phys. Discuss., 2017b.

DeCarlo, P. F., Kimmel, J. R., Trimborn, A., Northway, M. J., Jayne, J. T., Aiken, A. C., Gonin, M., Fuhrer, K., Horvath, T., Docherty, K. S., Worsnop, D. R., and Jimenez, J. L.: FieldDeployable, High-Resolution, Time-of-Flight Aerosol Mass Spectrometer, Anal. Chem., 78, 8281-8289, 2006.

Duplissy, J., Gysel, M., Alfarra, M. R., Dommen, J., Metzger, A., Prevot, A. S. H., Weingartner, E., Laaksonen, A., Raatikainen, T., Good, N., Turner, S. F., McFiggans, G., and Baltensperger, U.: Cloud forming potential of secondary organic aerosol under near atmospheric conditions, Geophys. Res. Lett., 35, L03818, https://doi.org/10.1029/2007GL031075, 2008.

Duplissy, J., DeCarlo, P. F., Dommen, J., Alfarra, M. R., Metzger, A., Barmpadimos, I., Prevot, A. S. H., Weingartner, E., Tritscher, T., Gysel, M., Aiken, A. C., Jimenez, J. L., Canagaratna, M. R., Worsnop, D. R., Collins, D. R., Tomlinson, J., and Baltensperger, U.: Relating hygroscopicity and composition of organic aerosol particulate matter, Atmos. Chem. Phys., 11, 1155-1165, https://doi.org/10.5194/acp-11-1155-2011, 2011. 
Dusek, U., Frank, G. P., Curtius, J., Drewnick, F., Schneider, J., Kürten, A., Rose, D., Andreae, M. O., Borrmann, S., and Pöschl, U.: Enhanced organic mass fraction and decreased hygroscopicity of cloud condensation nuclei $(\mathrm{CCN})$ during new particle formation events, Geophys. Res. Lett., 37, L03804, https://doi.org/10.1029/2009GL040930, 2010.

Ervens, B., Cubison, M. J., Andrews, E., Feingold, G., Ogren, J. A., Jimenez, J. L., Quinn, P. K., Bates, T. S., Wang, J., Zhang, Q., Coe, H., Flynn, M., and Allan, J. D.: CCN predictions using simplified assumptions of organic aerosol composition and mixing state: a synthesis from six different locations, Atmos. Chem. Phys., 10, 4795-4807, https://doi.org/10.5194/acp-104795-2010, 2010.

Fisch, G., Tota, J., Machado, L. A. T., Silva Dias, M. A. F., da F. Lyra, R. F., Nobre, C. A., Dolman, A. J., and Gash, J. H. C.: The convective boundary layer over pasture and forest in Amazonia, Theor. Appl. Climatol., 78, 47-59, 2004.

Frank, G. P., Dusek, U., and Andreae, M. O.: Technical note: A method for measuring size-resolved $\mathrm{CCN}$ in the atmosphere, Atmos. Chem. Phys. Discuss., https://doi.org/10.5194/acpd-64879-2006, in review, 2006.

Fry, J. L., Kiendler-Scharr, A., Rollins, A. W., Wooldridge, P. J., Brown, S. S., Fuchs, H., Dube, W., Mensah, A., dal Maso, M., Tillmann, R., Dorn, H. P., Brauers, T., and Cohen, R. C.: Organic nitrate and secondary organic aerosol yield from $\mathrm{NO}_{3}$ oxidation of beta-pinene evaluated using a gas-phase kinetics/aerosol partitioning model, Atmos. Chem. Phys., 9, 14311449, https://doi.org/10.5194/acp-9-1431-2009, 2009.

Ghan, S. J., Smith, S. J., Wang, M. H., Zhang, K., Pringle, K. J., Carslaw, K. S., Pierce, J. R., Bauer, S. E., and Adams, P. J.: A simple model of global aerosol indirect effects, J. Geophys. Res.-Atmos., 118, 6688-6707, 2013.

Good, N., Topping, D. O., Allan, J. D., Flynn, M., Fuentes, E., Irwin, M., Williams, P. I., Coe, H., and McFiggans, G.: Consistency between parameterisations of aerosol hygroscopicity and $\mathrm{CCN}$ activity during the RHaMBLe discovery cruise, Atmos. Chem. Phys., 10, 3189-3203, https://doi.org/10.5194/acp10-3189-2010, 2010.

Gunthe, S. S., King, S. M., Rose, D., Chen, Q., Roldin, P., Farmer, D. K., Jimenez, J. L., Artaxo, P., Andreae, M. O., Martin, S. T., and Pöschl, U.: Cloud condensation nuclei in pristine tropical rainforest air of Amazonia: size-resolved measurements and modeling of atmospheric aerosol composition and CCN activity, Atmos. Chem. Phys., 9, 7551-7575, https://doi.org/10.5194/acp9-7551-2009, 2009.

Guenther, A., Karl, T., Harley, P., Wiedinmyer, C., Palmer, P. I., and Geron, C.: Estimates of global terrestrial isoprene emissions using MEGAN (Model of Emissions of Gases and Aerosols from Nature), Atmos. Chem. Phys., 6, 3181-3210, https://doi.org/10.5194/acp-6-3181-2006, 2006.

Guenther, A. B., Jiang, X., Heald, C. L., Sakulyanontvittaya, T., Duhl, T., Emmons, L. K., and Wang, X.: The Model of Emissions of Gases and Aerosols from Nature version 2.1 (MEGAN2.1): an extended and updated framework for modeling biogenic emissions, Geosci. Model Dev., 5, 1471-1492, https://doi.org/10.5194/gmd-5-1471-2012, 2012.

Hamilton, D. S., Lee, L. A., Pringle, K. J., Reddington, C. L., Spracklen, D. V., and Carslaw, K. S.: Occurrence of pristine aerosol environments on a polluted planet, P. Natl. Acad. Sci. USA, 111, 18466-18471, 2014.

Heald, C. L., Wilkinson, M. J., Monson, R. K., Alo, C. A., Wang, G., and Guenther, A.: Response of isoprene emission to ambient $\mathrm{CO}_{2}$ changes and implications for global budgets, Glob. Change Biol., 15, 1127-1140, 2009.

Hori, M., Ohta, S., Murao, N., and Yamagata, S.: Activation capability of water soluble organic substances as CCN, J. Aerosol Sci., 34, 419-448, 2003.

Jimenez, J. L., Canagaratna, M. R., Donahue, N. M., Prevot, A. S. H., Zhang, Q., Kroll, J. H., DeCarlo, P. F., Allan, J. D., Coe, H., Ng, N. L., Aiken, A. C., Docherty, K. S., Ulbrich, I. M., Grieshop, A. P., Robinson, A. L., Duplissy, J., Smith, J. D., Wilson, K. R., Lanz, V. A., Hueglin, C., Sun, Y. L., Tian, J., Laaksonen, A., Raatikainen, T., Rautiainen, J., Vaattovaara, P., Ehn, M., Kulmala, M., Tomlinson, J. M., Collins, D. R., Cubison, M. J., Dunlea, E. J., Huffman, J. A., Onasch, T. B., Alfarra, M. R., Williams, P. I., Bower, K., Kondo, Y., Schneider, J., Drewnick, F., Borrmann, S., Weimer, S., Demerjian, K., Salcedo, D., Cottrell, L., Griffin, R., Takami, A., Miyoshi, T., Hatakeyama, S., Shimono, A., Sun, J. Y., Zhang, Y. M., Dzepina, K., Kimmel, J. R., Sueper, D., Jayne, J. T., Herndon, S. C., Trimborn, A. M., Williams, L. R., Wood, E. C., Middlebrook, A. M., Kolb, C. E., Baltensperger, U., and Worsnop, D. R.: Evolution of organic aerosols in the atmosphere, Science, 326, 1525-1529, 2009.

Kammermann, L., Gysel, M., Weingartner, E., Herich, H., Cziczo, D. J., Holst, T., Svenningsson, B., Arneth, A., and Baltensperger, U.: Subarctic atmospheric aerosol composition: 3. Measured and modeled properties of cloud condensation nuclei, J. Geophys. Res., 115, D04202, https://doi.org/10.1029/2009JD012447, 2010.

Kesselmeier, J., Kuhn, U., Rottenberger, S., Biesenthal, T., Wolf, A., Schebeske, G., Andreae, M. O., Ciccioli, P., Brancaleoni, E., Frattoni, M., Oliva, S. T., Botelho, M. L., Silva, C. M. A., and Tavares, T. M.: Concentrations and species composition of atmospheric volatile organic compounds (VOCs) as observed during the wet and dry season in Rondonia (Amazonia), J. Geophys. Res.-Atmos., 107, 8053, https://doi.org/10.1029/2000JD000267, 2002.

King, S. M., Rosenoern, T., Shilling, J. E., Chen, Q., and Martin, S. T.: Increased cloud activation potential of secondary organic aerosol for atmospheric mass loadings, Atmos. Chem. Phys., 9, 2959-2971, https://doi.org/10.5194/acp-9-2959-2009, 2009.

Kuhn, U., Andreae, M. O., Ammann, C., Araújo, A. C., Brancaleoni, E., Ciccioli, P., Dindorf, T., Frattoni, M., Gatti, L. V., Ganzeveld, L., Kruijt, B., Lelieveld, J., Lloyd, J., Meixner, F. X., Nobre, A. D., Pöschl, U., Spirig, C., Stefani, P., Thielmann, A., Valentini, R., and Kesselmeier, J.: Isoprene and monoterpene fluxes from Central Amazonian rainforest inferred from towerbased and airborne measurements, and implications on the atmospheric chemistry and the local carbon budget, Atmos. Chem. Phys., 7, 2855-2879, https://doi.org/10.5194/acp-7-2855-2007, 2007.

Kuhn, U., Ganzeveld, L., Thielmann, A., Dindorf, T., Schebeske, G., Welling, M., Sciare, J., Roberts, G., Meixner, F. X., Kesselmeier, J., Lelieveld, J., Kolle, O., Ciccioli, P., Lloyd, J., Trentmann, J., Artaxo, P., and An- 
dreae, M. O.: Impact of Manaus City on the Amazon Green Ocean atmosphere: ozone production, precursor sensitivity and aerosol load, Atmos. Chem. Phys., 10, 9251-9282, https://doi.org/10.5194/acp-10-9251-2010, 2010.

Kumar, P. P., Broekhuizen, K., and Abbatt, J. P. D.: Organic acids as cloud condensation nuclei: laboratory studies of highly soluble and insoluble species, Atmos. Chem. Phys., 3, 509-520, https://doi.org/10.5194/acp-3-509-2003, 2003.

Kuwata, M., Zorn, S. R., and Martin, S. T.: Using elemental ratios to predict the density of organic material composed of carbon, hydrogen, and oxygen, Environ. Sci. Technol., 46, 787-794, 2012.

Lambe, A. T., Onasch, T. B., Massoli, P., Croasdale, D. R., Wright, J. P., Ahern, A. T., Williams, L. R., Worsnop, D. R., Brune, W. H., and Davidovits, P.: Laboratory studies of the chemical composition and cloud condensation nuclei (CCN) activity of secondary organic aerosol (SOA) and oxidized primary organic aerosol (OPOA), Atmos. Chem. Phys., 11, 8913-8928, https://doi.org/10.5194/acp-11-8913-2011, 2011.

Lance, S., Raatikainen, T., Onasch, T., Worsnop, D., Yu, X. Y., Alexander, M. L., Stolzenburg, M. R., McMurry, P. H., Smith, J. N., and Nenes, A.: Aerosol mixing-state, hygroscopic growth and cloud activation efficiency during MIRAGE 2006, Atmos. Chem. Phys., 13, 5049-5062, https://doi.org/10.5194/acp-13-5049-2013, 2013.

Lanz, V. A., Alfarra, M. R., Baltensperger, U., Buchmann, B., Hueglin, C., Szidat, S., Wehrli, M. N., Wacker, L., Weimer, S., Caseiro, A., Puxbaum, H., and Prevot, A. S. H.: Source attribution of submicron organic aerosols during wintertime inversions by advanced factor analysis of aerosol mass spectra, Environ. Sci. Technol., 42, 214-220, 2008.

Lathem, T. L., Beyersdorf, A. J., Thornhill, K. L., Winstead, E. L., Cubison, M. J., Hecobian, A., Jimenez, J. L., Weber, R. J., Anderson, B. E., and Nenes, A.: Analysis of CCN activity of Arctic aerosol and Canadian biomass burning during summer 2008, Atmos. Chem. Phys., 13, 2735-2756, https://doi.org/10.5194/acp13-2735-2013, 2013.

Liu, X. and Wang, J.: How important is organic aerosol hygroscopicity to aerosol indirect forcing?, Environ. Res. Lett., 5, 044010, https://doi.org/10.1088/1748-9326/5/4/044010, 2010.

Liu, Y., Brito, J., Dorris, M. R., Rivera-Rios, J. C., Seco, R., Bates, K. H., Artaxo, P., Duvoisin, S., Keutsch, F. N., Kim, S., Goldstein, A. H., Guenther, A. B., Manzi, A. O., Souza, R. A. F., Springston, S. R., Watson, T. B., McKinney, K. A., and Martin, S. T.: Isoprene photochemistry over the Amazon rainforest, P. Natl. Acad. Sci. USA, 113, 6125-6130, 2016.

Martin, S. T., Andreae, M. O., Althausen, D., Artaxo, P., Baars, H., Borrmann, S., Chen, Q., Farmer, D. K., Guenther, A., Gunthe, S. S., Jimenez, J. L., Karl, T., Longo, K., Manzi, A., Müller, T., Pauliquevis, T., Petters, M. D., Prenni, A. J., Pöschl, U., Rizzo, L. V., Schneider, J., Smith, J. N., Swietlicki, E., Tota, J., Wang, J., Wiedensohler, A., and Zorn, S. R.: An overview of the Amazonian Aerosol Characterization Experiment 2008 (AMAZE-08), Atmos. Chem. Phys., 10, 1141511438, https://doi.org/10.5194/acp-10-11415-2010, 2010a.

Martin, S. T., Andreae, M. O., Artaxo, P., Baumgardner, D., Chen, Q., Goldstein, A. H., Guenther, A., Heald, C. L., MayolBracero, O. L., McMurry, P. H., Pauliquevis, T., Pöschl, U., Prather, K. A., Roberts, G. C., Saleska, S. R., Silva Dias, M. A., Spracklen, D. V., Swietlicki, E., and Trebs, I.: Sources and properties of Amazonian aerosol particles, Rev. Geophys., 48, RG2002, https://doi.org/10.1029/2008RG000280, 2010b.

Martin, S. T., Artaxo, P., Machado, L. A. T., Manzi, A. O., Souza, R. A. F., Schumacher, C., Wang, J., Andreae, M. O., Barbosa, H. M. J., Fan, J., Fisch, G., Goldstein, A. H., Guenther, A., Jimenez, J. L., Pöschl, U., Silva Dias, M. A., Smith, J. N., and Wendisch, M.: Introduction: Observations and Modeling of the Green Ocean Amazon (GoAmazon2014/5), Atmos. Chem. Phys., 16, 47854797, https://doi.org/10.5194/acp-16-4785-2016, 2016.

Martin, S. T., Artaxo, P., Machado, L., Manzi, A. O., Souza, R. A. F., Schumacher, C., Wang, J., Biscaro, T., Brito, J., Calheiros, A., Jardine, K., Medeiros, A., Portela, B., Sá, S. S. d., Adachi, K., Aiken, A. C., Albrecht, R., Alexander, L., Andreae, M. O., Barbosa, H. M. J., Buseck, P., Chand, D., Comstock, J. M., Day, D. A., Dubey, M., Fan, J., Fast, J., Fisch, G., Fortner, E., Giangrande, S., Gilles, M., Goldstein, A. H., Guenther, A., Hubbe, J., Jensen, M., Jimenez, J. L., Keutsch, F. N., Kim, S., Kuang, C., Laskin, A., McKinney, K., Mei, F., Miller, M., Nascimento, R., Pauliquevis, T., Pekour, M., Peres, J., Petäjä, T., Pöhlker, C., Pöschl, U., Rizzo, L., Schmid, B., Shilling, J. E., Dias, M. A. S., Smith, J. N., Tomlinson, J. M., Tóta, J., and Wendisch, M.: The Green Ocean Amazon Experiment (GoAmazon2014/5) observes pollution affecting gases, aerosols, clouds, and rainfall over the Rain Forest, B. Am. Meteorol. Soc., 98, 981-997, https://doi.org/10.1175/BAMS-D-15$00221.1,2017$.

Massoli, P., Lambe, A. T., Ahern, A. T., Williams, L. R., Ehn, M., Mikkila, J., Canagaratna, M. R., Brune, W. H., Onasch, T. B., Jayne, J. T., Petaja, T., Kulmala, M., Laaksonen, A., Kolb, C. E., Davidovits, P., and Worsnop, D. R.: Relationship between aerosol oxidation level and hygroscopic properties of laboratory generated secondary organic aerosol (SOA) particles, Geophys. Res. Lett., 37, L24801, https://doi.org/10.1029/2010GL045258, 2010.

McFiggans, G., Artaxo, P., Baltensperger, U., Coe, H., Facchini, M. C., Feingold, G., Fuzzi, S., Gysel, M., Laaksonen, A., Lohmann, U., Mentel, T. F., Murphy, D. M., O’Dowd, C. D., Snider, J. R., and Weingartner, E.: The effect of physical and chemical aerosol properties on warm cloud droplet activation, Atmos. Chem. Phys., 6, 2593-2649, https://doi.org/10.5194/acp6-2593-2006, 2006.

Mei, F., Hayes, P. L., Ortega, A. M., Taylor, J. W., Allan, J. D., Gilman, J. B., Kuster, W. C., de Gouw, J. A., Jimenez, J. L., and Wang, J.: Droplet activation properties of organic aerosols observed at an urban site during CalNex-LA, J. Geophys. Res., 118, 2903-2917, 2013a.

Mei, F., Setyan, A., Zhang, Q., and Wang, J.: CCN activity of organic aerosols observed downwind of urban emissions during CARES, Atmos. Chem. Phys., 13, 12155-12169, https://doi.org/10.5194/acp-13-12155-2013, 2013 b.

Mikhailov, E., Vlasenko, S., Rose, D., and Pöschl, U.: Mass-based hygroscopicity parameter interaction model and measurement of atmospheric aerosol water uptake, Atmos. Chem. Phys., 13, 717740, https://doi.org/10.5194/acp-13-717-2013, 2013.

Moore, R. H., Nenes, A., and Medina, J.: Scanning mobility CCN analysis - a method for fast measurements of size-resolved CCN distributions and activation kinetics, Aerosol Sci. Tech., 44, 861871, 2010. 
Moore, R. H., Bahreini, R., Brock, C. A., Froyd, K. D., Cozic, J., Holloway, J. S., Middlebrook, A. M., Murphy, D. M., and Nenes, A.: Hygroscopicity and composition of Alaskan Arctic CCN during April 2008, Atmos. Chem. Phys., 11, 11807-11825, https://doi.org/10.5194/acp-11-11807-2011, 2011.

Moore, R. H., Cerully, K., Bahreini, R., Brock, C. A., Middlebrook, A. M., and Nenes, A.: Hygroscopicity and composition of California CCN during summer 2010, J. Geophys. Res., 117, D00V12, https://doi.org/10.1029/2011JD017352, 2012.

Nenes, A., Pandis, S., and Pilinis, C.: ISORROPIA: a new thermodynamic equilibrium model for multiphase multicomponent inorganic aerosols, Aquat. Geochem., 4, 123-152, 1998.

Ng, N. L., Canagaratna, M. R., Zhang, Q., Jimenez, J. L., Tian, J., Ulbrich, I. M., Kroll, J. H., Docherty, K. S., Chhabra, P. S., Bahreini, R., Murphy, S. M., Seinfeld, J. H., Hildebrandt, L., Donahue, N. M., DeCarlo, P. F., Lanz, V. A., Prevot, A. S. H., Dinar, E., Rudich, Y., and Worsnop, D. R.: Organic aerosol components observed in Northern Hemispheric datasets from Aerosol Mass Spectrometry, Atmos. Chem. Phys., 10, 46254641, https://doi.org/10.5194/acp-10-4625-2010, 2010.

Ng, N. L., Herndon, S. C., Trimborn, A., Canagaratna, M. R., Croteau, P. L., Onasch, T. B., Sueper, D., Worsnop, D. R., Zhang, Q., Sun, Y. L., and Jayne, J. T.: An Aerosol Chemical Speciation Monitor (ACSM) for routine monitoring of the composition and mass concentrations of ambient aerosol, Aerosol Sci. Tech., 45, 780-794, 2011.

Pajunoja, A., Lambe, A. T., Hakala, J., Rastak, N., Cummings, M. J., Brogan, J. F., Hao, L. Q., Paramonov, M., Hong, J., Prisle, N. L., Malila, J., Romakkaniemi, S., Lehtinen, K. E. J., Laaksonen, A., Kulmala, M., Massoli, P., Onasch, T. B., Donahue, N. M., Riipinen, I., Davidovits, P., Worsnop, D. R., Petaja, T., and Virtanen, A.: Adsorptive uptake of water by semisolid secondary organic aerosols, Geophys. Res. Lett., 42, 3063-3068, 2015.

Park, K., Kittelson, D., Zachariah, M., and McMurry, P.: Measurement of inherent material density of nanoparticle agglomerates, J. Nanopart. Res., 6, 267-272, 2004.

Petters, M. D. and Kreidenweis, S. M.: A single parameter representation of hygroscopic growth and cloud condensation nucleus activity, Atmos. Chem. Phys., 7, 1961-1971, https://doi.org/10.5194/acp-7-1961-2007, 2007.

Petters, M. D., Prenni, A. J., Kreidenweis, S. M., and DeMott, P. J.: On measuring the critical diameter of cloud condensation nuclei using mobility selected aerosol, Aerosol Sci. Tech., 41, 907-913, 2007.

Pöhlker, M. L., Pöhlker, C., Klimach, T., Hrabe de Angelis, I., Barbosa, H. M. J., Brito, J., Carbone, S., Cheng, Y., Chi, X., Ditas, F., Ditz, R., Gunthe, S. S., Kesselmeier, J., Könemann, T., Lavrič, J. V., Martin, S. T., Moran-Zuloaga, D., Rose, D., Saturno, J., Su, H., Thalman, R., Walter, D., Wang, J., Wolff, S., Artaxo, P., Andreae, M. O., and Pöschl, U.: Long-term observations of cloud condensation nuclei in the Amazon rain forest - Part 1: Aerosol size distribution, hygroscopicity, and new model parametrizations for CCN prediction, Atmos. Chem. Phys., 16, 15709-15740, https://doi.org/10.5194/acp-16-157092016, 2016.

Pöschl, U., Martin, S. T., Sinha, B., Chen, Q., Gunthe, S. S., Huffman, J. A., Borrmann, S., Farmer, D. K., Garland, R. M., Helas, G., Jimenez, J. L., King, S. M., Manzi, A., Mikhailov, E.,
Pauliquevis, T., Petters, M. D., Prenni, A. J., Roldin, P., Rose, D., Schneider, J., Su, H., Zorn, S. R., Artaxo, P., and Andreae, M. O.: Rainforest aerosols as biogenic nuclei of clouds and precipitation in the Amazon, Science, 329, 1513-1516, 2010.

Prenni, A. J., Petters, M. D., Kreidenweis, S. M., DeMott, P. J., and Ziemann, P. J.: Cloud droplet activation of secondary organic aerosol, J. Geophys. Res., 112, D10223, https://doi.org/10.1029/2006JD007963, 2007.

Raymond, T. M. and Pandis, S. N.: Formation of cloud droplets by multicomponent organic particles, J. Geophys. Res., 108, 4469, https://doi.org/10.1029/2003JD003503, 2003.

Reutter, P., Su, H., Trentmann, J., Simmel, M., Rose, D., Gunthe, S. S., Wernli, H., Andreae, M. O., and Ps"chl, U.: Aerosol- and updraft-limited regimes of cloud droplet formation: influence of particle number, size and hygroscopicity on the activation of cloud condensation nuclei (CCN), Atmos. Chem. Phys., 9, 70677080, https://doi.org/10.5194/acp-9-7067-2009, 2009.

Rissler, J., Swietlicki, E., Zhou, J., Roberts, G., Andreae, M. O., Gatti, L. V., and Artaxo, P.: Physical properties of the submicrometer aerosol over the Amazon rain forest during the wetto-dry season transition - comparison of modeled and measured CCN concentrations, Atmos. Chem. Phys., 4, 2119-2143, https://doi.org/10.5194/acp-4-2119-2004, 2004.

Rissler, J., Vestin, A., Swietlicki, E., Fisch, G., Zhou, J., Artaxo, P., and Andreae, M. O.: Size distribution and hygroscopic properties of aerosol particles from dry-season biomass burning in Amazonia, Atmos. Chem. Phys., 6, 471-491, https://doi.org/10.5194/acp-6-471-2006, 2006.

Rissman, T. A., Nenes, A., and Seinfeld, J. H.: Chemical amplification (or dampening) of the Twomey Effect: conditions derived from droplet activation theory, J. Atmos. Sci., 61, 919-930, 2004.

Riva, M., Bell, D. M., Hansen, A. M. K., Drozd, G. T., Zhang, Z. F., Gold, A., Imre, D., Surratt, J. D., Glasius, M., and Zelenyuk, A.: Effect of organic coatings, humidity and aerosol acidity on multiphase chemistry of isoprene epoxydiols, Environ. Sci. Technol., 50, 5580-5588, 2016.

Roberts, G. C., Andreae, M. O., Zhou, J., and Artaxo, P.: Cloud condensation nuclei in the Amazon Basin: "marine" conditions over a continent?, Geophys. Res. Lett., 28, 2807-2810, 2001.

Roberts, G. C., Artaxo, P., Zhou, J., Swietlicki, E., and Andreae, M. O.: Sensitivity of CCN spectra on chemical and physical properties of aerosol: a case study from the Amazon Basin, J. Geophys. Res.-Atmos., 107, 37-18, 2002.

Rose, D., Gunthe, S. S., Mikhailov, E., Frank, G. P., Dusek, U., Andreae, M. O., and Poschl, U.: Calibration and measurement uncertainties of a continuous-flow cloud condensation nuclei counter (DMT-CCNC): CCN activation of ammonium sulfate and sodium chloride aerosol particles in theory and experiment, Atmos. Chem. Phys., 8, 1153-1179, https://doi.org/10.5194/acp8-1153-2008, 2008.

Rose, D., Nowak, A., Achtert, P., Wiedensohler, A., Hu, M., Shao, M., Zhang, Y., Andreae, M. O., and Pöschl, U.: Cloud condensation nuclei in polluted air and biomass burning smoke near the mega-city Guangzhou, China - Part 1: Size-resolved measurements and implications for the modeling of aerosol particle hygroscopicity and CCN activity, Atmos. Chem. Phys., 10, 33653383, https://doi.org/10.5194/acp-10-3365-2010, 2010.

Rosenfeld, D., Lohmann, U., Raga, G. B., Dowd, C. D., Kulmala, M., Fuzzi, S., Reissell, A., and Andreae, M. O.: Flood 
or drought: how do aerosols affect precipitation?, Science, 321, 1309-1313, https://doi.org/10.1126/science.1160606, 2008.

Schwantes, R. H., Teng, A. P., Nguyen, T. B., Coggon, M. M., Crounse, J. D., St Clair, J. M., Zhang, X., Schilling, K. A., Seinfeld, J. H., and Wennberg, P. O.: Isoprene $\mathrm{NO}_{3}$ oxidation products from the $\mathrm{RO}_{2}+\mathrm{HO}_{2}$ pathway, J. Phys. Chem. A, 119, 10158-10171, 2015.

Shantz, N. C., Leaitch, W. R., Phinney, L., Mozurkewich, M., and Toom-Sauntry, D.: The effect of organic compounds on the growth rate of cloud droplets in marine and forest settings, Atmos. Chem. Phys., 8, 5869-5887, https://doi.org/10.5194/acp-85869-2008, 2008.

Sullivan, R. C., Moore, M. J. K., Petters, M. D., Kreidenweis, S. M., Roberts, G. C., and Prather, K. A.: Effect of chemical mixing state on the hygroscopicity and cloud nucleation properties of calcium mineral dust particles, Atmos. Chem. Phys., 9, 33033316, https://doi.org/10.5194/acp-9-3303-2009, 2009.

Twomey, S.: The influence of pollution on the shortwave albedo of clouds, J. Atmos. Sci., 34, 1149-1152, 1977.

Ulbrich, I. M., Canagaratna, M. R., Zhang, Q., Worsnop, D. R., and Jimenez, J. L.: Interpretation of organic components from Positive Matrix Factorization of aerosol mass spectrometric data, Atmos. Chem. Phys., 9, 2891-2918, https://doi.org/10.5194/acp-92891-2009, 2009.

Vestin, A., Rissler, J., Swietlicki, E., Frank, G. P., and Andreae, M. O.: Cloud-nucleating properties of the Amazonian biomass burning aerosol: cloud condensation nuclei measurements and modeling, J. Geophys. Res.-Atmos., 112, 1309-1313, https://doi.org/10.1126/science.1160606, 2007.

Wang, J.: Effects of spatial and temporal variations in aerosol properties on mean cloud albedo, J. Geophys. Res., 112, D14201, https://doi.org/10.1029/2006JD008104, 2007.

Wang, J., Lee, Y. N., Daum, P. H., Jayne, J., and Alexander, M. L.: Effects of aerosol organics on cloud condensation nucleus (CCN) concentration and first indirect aerosol effect, Atmos. Chem. Phys., 8, 6325-6339, https://doi.org/10.5194/acp-8-6325-2008, 2008.

Wang, J., Krejci, R., Giangrandel, S., Kuang, C., Barbosa, H. M. J., Brito, J., Carbone, S., Chi, X. G., Comstock, J., Ditas, F., Lavric, J., Manninen, H. E., Mei, F., Moran-Zuloaga, D., Pohlker, C., Pohlker, M. L., Saturno, J., Schmid, B., Souza, R. A. F., Springston, S. R., Tomlinson, J. M., Toto, T., Walter, D., Wimmer, D., Smith, J. N., Kulmala, M., Machado, L. A. T., Artaxo, P., Andreae, M. O., Petaja, T., and Martin, S. T.: Amazon boundary layer aerosol concentration sustained by vertical transport during rainfall, Nature, 539, 416-419, 2016a.

Wang, Q. Q., Saturno, J., Chi, X., Walter, D., Lavric, J. V., Moran-Zuloaga, D., Ditas, F., Pohlker, C., Brito, J., Carbone, S., Artaxo, P., and Andreae, M. O.: Modeling investigation of light-absorbing aerosols in the Amazon Basin during the wet season, Atmos. Chem. Phys., 16, 14775-14794, https://doi.org/10.5194/acp-16-14775-2016, $2016 \mathrm{~b}$.

Wex, H., Petters, M. D., Carrico, C. M., Hallbauer, E., Massling, A., McMeeking, G. R., Poulain, L., Wu, Z., Kreidenweis, S. M., and Stratmann, F.: Towards closing the gap between hygroscopic growth and activation for secondary organic aerosol: Part $1-$ Evidence from measurements, Atmos. Chem. Phys., 9, 3987-3997, https://doi.org/10.5194/acp-9-3987-2009, 2009.
Whitehead, J. D., Gallagher, M. W., Dorsey, J. R., Robinson, N., Gabey, A. M., Coe, H., McFiggans, G., Flynn, M. J., Ryder, J., Nemitz, E., and Davies, F.: Aerosol fluxes and dynamics within and above a tropical rainforest in South-East Asia, Atmos. Chem. Phys., 10, 9369-9382, https://doi.org/10.5194/acp10-9369-2010, 2010.

Whitehead, J. D., Darbyshire, E., Brito, J., Barbosa, H. M. J., Crawford, I., Stern, R., Gallagher, M. W., Kaye, P. H., Allan, J. D., Coe, H., Artaxo, P., and McFiggans, G.: Biogenic cloud nuclei in the central Amazon during the transition from wet to dry season, Atmos. Chem. Phys., 16, 9727-9743, https://doi.org/10.5194/acp-16-9727-2016, 2016.

Williams, E., Rosenfeld, D., Madden, N., Gerlach, J., Gears, N., Atkinson, L., Dunnemann, N., Frostrom, G., Antonio, M., Biazon, B., Camargo, R., Franca, H., Gomes, A., Lima, M., Machado, R., Manhaes, S., Nachtigall, L., Piva, H., Quintiliano, W., Machado, L., Artaxo, P., Roberts, G., Renno, N., Blakeslee, R., Bailey, J., Boccippio, D., Betts, A., Wolff, D., Roy, B., Halverson, J., Rickenbach, T., Fuentes, J., and Avelino, E.: Contrasting convective regimes over the Amazon: implications for cloud electrification, J. Geophys. Res.-Atmos., 107, 8082, https://doi.org/10.1029/2007JD008565, 2002.

Xu, L., Guo, H. Y., Boyd, C. M., Klein, M., Bougiatioti, A., Cerully, K. M., Hite, J. R., Isaacman-VanWertz, G., Kreisberg, N. M., Knote, C., Olson, K., Koss, A., Goldstein, A. H., Hering, S. V., de Gouw, J., Baumann, K., Lee, S. H., Nenes, A., Weber, R. J., and Ng, N. L.: Effects of anthropogenic emissions on aerosol formation from isoprene and monoterpenes in the southeastern United States, P. Natl. Acad. Sci. USA, 112, 37-42, 2015a.

Xu, L., Suresh, S., Guo, H., Weber, R. J., and Ng, N. L.: Aerosol characterization over the southeastern United States using high-resolution aerosol mass spectrometry: spatial and seasonal variation of aerosol composition and sources with a focus on organic nitrates, Atmos. Chem. Phys., 15, 7307-7336, https://doi.org/10.5194/acp-15-7307-2015, 2015 b.

Zhang, Q., Canagaratna, M. R., Jayne, J. T., Worsnop, D. R., and Jimenez, J.-L.: Time- and size-resolved chemical composition of submicron particles in Pittsburgh: implications for aerosol sources and processes, J. Geophys. Res.-Atmos., 110, D07S09, https://doi.org/10.1029/2004JD004649, 2005.

Zhang, Q., Jimenez, J. L., Canagaratna, M. R., Allan, J. D., Coe, H., Ulbrich, I., Alfarra, M. R., Takami, A., Middlebrook, A. M., Sun, Y. L., Dzepina, K., Dunlea, E., Docherty, K., DeCarlo, P. F., Salcedo, D., Onasch, T., Jayne, J. T., Miyoshi, T., Shimono, A., Hatakeyama, S., Takegawa, N., Kondo, Y., Schneider, J., Drewnick, F., Borrmann, S., Weimer, S., Demerjian, K., Williams, P., Bower, K., Bahreini, R., Cottrell, L., Griffin, R. J., Rautiainen, J., Sun, J. Y., Zhang, Y. M., and Worsnop, D. R.: Ubiquity and dominance of oxygenated species in organic aerosols in anthropogenically-influenced Northern Hemisphere midlatitudes, Geophys. Res. Lett., 34, L13801, https://doi.org/10.1029/2007GL029979, 2007.

Zhou, J., Swietlicki, E., Hansson, H. C., and Artaxo, P.: Submicrometer aerosol particle size distribution and hygroscopic growth measured in the Amazon rain forest during the wet season, J. Geophys. Res.-Atmos., 107, 8055, https://doi.org/10.1029/2000JD000203, 2002. 